NBER WORKING PAPER SERIES

\title{
CREDIT CHANNEL OR CREDIT ACTIONS? AN INTERPRETATION OF THE POSTWAR \\ TRANSMISSION MECHANISM
}

\section{Christina D. Romer}

David H. Romer

Working Paper No. 4485

NATIONAL BUREAU OF ECONOMIC RESEARCH

1050 Massachusetts Avenue

Cambridge, MA 02138

October, 1993

This paper is part of NBER's research program in Economic Fluctuations and Monetary Economics. Any opinions expressed are those of the authors and not those of the National Bureau of Economic Research. 
NBER Working Paper \#4485

October 1993

\title{
CREDIT CHANNEL OR CREDIT ACTIONS? \\ AN INTERPRETATION OF THE POSTWAR \\ TRANSMISSION MECHANISM
}

\begin{abstract}
This paper shows that the disproportionate impact of tight monetary policy on banks' ability to lend is largely the consequence of Federal Reserve actions aimed at reducing bank loans directly, rather than an inherent feature of the monetary transmission mechanism. We provide two types of evidence for this conclusion. First, a detailed examination of nine postwar episodes of contractionary monetary policy shows that while short-term interest rates always rose in response to tight policy, banks typically found ways of maintaining lending despite the falls in reserves. Banks' ability to lend was particularly affected by tight policy only when the Federal Reserve undertook actions, such as special reserve requirements, moral suasion, or explicit credit controls, to restrain bank lending directly. Second, simple regressions show that Federal Reserve credit actions have large and significant effects on the composition of external finance between bank loans and commercial paper and on the spread between the prime bank loan rate and the commercial paper rate, and that a bank credit channel of monetary transmission is not needed to explain the movements in these variables in response to tight policy.
\end{abstract}

Christina D. Romer Department of Economics University of California, Berkeley Berkeley, CA 94720 and NBER

\author{
David H. Romer \\ Department of Economics \\ University of California, Berkeley \\ Berkeley, CA 94720 \\ and NBER
}




\title{
CREDIT CHANNEL OR CREDIT ACTIONS?
}

\section{An Interpretation of the Postwar Transmission Mechanism}

\author{
Christina D. Romer and David H. Romer*
}

\section{INTRODUCTION}

Monetary policy actions affect credit flows in two ways. First, tightening of policy leads to increases in the overall level of interest rates. When prevailing interest rates rise, borrowers may choose to borrow less, and lenders may choose to ration funds to certain types of borrowers. This is the "interest rate side" of the monetary transmission mechanism. Second, monetary policy actions may directly affect the ability of certain types of lenders to obtain funds. Because banks obtain a large portion of their funds from instruments subject to reserve requirements, open-market operations, which alter the quantity of reserves, may affect the opportunity cost of funds to banks beyond their impact on general interest rates. Monetary policy may therefore particularly affect firms and households that depend on banks for loans. Such effects on the ability of particular classes of lenders to

* This paper was prepared for a symposium on "Changing Capital Markets: Implications for Monetary Policy" sponsored by the Federal Reserve Bank of Kansas City, Jackson Hole, Wyoming, August 19-21, 1993. We are grateful to Anil Kashyap and David Wilcox for providing data, computer programs, and helpful comments, and to our discussants, Charles Freedman and Mark Gertler, for insightful comments and suggestions. We also received helpful comments and suggestions from Laurence Ball, Fischer Black, William English, Stanley Fischer, Benjamin Friedman, Michael Gibson, Philip Jefferson, Donald Kohn, David Lindsey, and Glenn Rudebusch. We are grateful to Matthew Jones for research assistance and to the National Science Foundation and the Alfred P. Sloan Foundation for financial support. 
obtain funds are the "credit side" of the transmission mechanism. ${ }^{1}$

Both of these components of the monetary transmission mechanism could be affected by recent changes in American financial institutions and regulations. For example, the development of substitutes for demand deposits and currency, such as money market mutual funds, may lessen the Federal Reserve's ability to control short-term interest rates. Similarly, banks' increased reliance on non-deposit sources of funds, such as certificates of deposit, and the growth of alternatives to bank loans, such as commercial paper and finance company loans, may reduce the ability of Federal Reserve actions to influence the supply of bank loans.

To understand how these recent changes in financial markets and regulations have actually changed the monetary transmission mechanism, one has to understand the components and functioning of the transmission mechanism in the past. To this end, Section II of the paper is devoted to a systematic analysis of the transmission mechanism in episodes of contractionary Federal Reserve policy in the postwar era.

1 See Bernanke and Blinder (1988) for a simple theoretical model of this effect. Kashyap and Stein (1993) survey work in this area. Of course, credit market imperfections are also likely to play a role in the interest rate side of the transmission mechanism. For example, tight monetary policy makes loans riskier by increasing firms' interest costs and reducing overall economic activity. This in turn is likely to reduce the availability of credit to smaller, less established firms relative to larger, older firms (see for example Gertler and Gilchrist, 1992). Because it is difficult to see how recent financial market innovations could have significantly affected this component of the transmission mechanism, in this paper we focus on the narrowly defined "credit side" of the transmission mechanism rather than attempting to consider credit market imperfections in general. For analyses of more general credit market effects of monetary policy, see Oliner and Rudebusch (1992), Morgan (1992), Kashyap, Lamont, and Stein (1993), and Gertler and Gilchrist (1992). For analyses of changes in recent decades in other aspects in the transmission mechanism, see Friedman (1989) and Bosworth (1989). 
This narrative analysis suggests three important facts about the postwar transmission mechanism. First, there has been an interest rate channel throughout the postwar era. Even though financial institutions have changed substantially over time, tightening by the Federal Reserve has consistently led to significant rises in interest rates. Second, even though financial markets have become more diversified and less regulated in recent years, the U.S. financial system has been remarkably flexible throughout the postwar era. In response to contractions by the Federal Reserve, banks in the 1950s, 1960s, and 1970s found ways of raising funds and adjusting their portfolios so that they could maintain lending. And third, to the degree that banks' ability to lend was reduced during monetary contractions, it was typically because the Federal Reserve (often in conjunction with Congress and the President) used regulatory actions and moral suasion to restrain bank lending directly, not because of an inherent link between monetary tightening and bank loans. ${ }^{2}$

In Section III, we supplement these narrative accounts with simple statistical tests of the effects of general monetary tightening and direct credit actions on the availability of bank loans and on real activity. We find that direct credit actions are followed by large, rapid, and statistically significant decreases in the quantity of bank lending relative to commercial paper

2 Our conclusion about the importance of policy actions and regulations in limiting banks' ability to lend is consistent with Owens and Schreft's (1993) conclusion that policy actions are the source of credit crunches. The type of credit market disruption we focus on, however, differs fundamentally from that considered by Owens and Schreft. Their focus is on periods of "sharply increased nonprice credit rationing" by any lenders $(1993$, p. 2). Our interest, in contrast, is in policy-induced limitations on banks' ability to lend, regardless of whether they result in credit rationing, and regardless of whether they result from an inherent link between monetary policy and bank lending or from actions aimed at either banks' access to funds or their ability to use those funds. 
issuance (the "mix") and increases in the difference between the interest rates on bank loans and on commercial paper (the "spread"). Thus the regressions confirm the narrative evidence that the direct credit actions disrupt bank lending.

The regression results concerning the impact of general tightening on banks' ability to lend are less clear-cut. Kashyap, Stein, and Wilcox (1993) demonstrate that periods of tight policy are associated with declines in the mix and rises in the spread. They interpret these findings as evidence of a bank credit channel of open-market operations. Subsequent research, however, has shown that substantial parts of these movements reflect changes in the relative riskiness of different types of borrowers, rather than in the relative ability of different types of lenders to obtain funds (Gertler and Gilchrist, 1993; Oliner and Rudebusch, 1993). We find that including a dummy variable for Federal Reserve credit actions eliminates a large part of the remaining estimated effect of general monetary policy on the mix and the spread. Thus the regression results are consistent with the narrative evidence suggesting the absence of a significant bank credit channel of monetary transmission for open-market operations.

In contrast to the results for lending, the regressions for real output are fairly clear concerning the effects of general tightening, but somewhat ambiguous concerning the effects of credit actions. Controlling for the effects of Federal Reserve credit actions does not affect our earlier finding (Romer and Romer, 1989, 1992) that Federal Reserve shifts to antiinflationary policy are followed by large and statistically significant declines in real activity. The impact of the credit actions, on the other hand, is not precisely estimated. When the general policy shifts are controlled for, the point estimates suggest that the credit actions lead to moderate declines in real output. But neither the hypothesis that the effect is zero nor the hypothesis that it is considerably larger can be rejected. 
Taken together, the narrative and statistical evidence suggests a new candidate interpretation of the credit side of the transmission mechanism. Monetary policy has a large impact on banks' ability to lend only when open-market operations are supplemented by actions aimed directly at restricting lending. At the same time, the main real effects of monetary policy come from the interest rate effects of open-market operations rather than from these credit actions.

This view of the interest rate and credit sides of monetary transmission in the postwar era implies that the recent changes in financial market institutions and regulations should only affect the transmission mechanism if they fundamentally alter the ability of the Federal Reserve to affect interest rates or to curtail lending directly. In Section IV we argue that there are neither empirical nor theoretical reasons to expect the Federal Reserve's control of interest rates to diminish in the foreseeable future. We also find that while the role of banks has certainly changed over time, banks are still central to firm finance and bank loans would still respond to direct credit actions. Thus, the central elements of the transmission mechanism have not been altered by recent institutional and regulatory changes.

While our analysis suggests that recent changes in financial markets have not fundamentally changed the transmission mechanism, this does not imply that the transmission mechanism has not changed for other reasons. In particular, while the interest rate component of monetary transmission may have been relatively constant, the credit component appears to have changed substantially. Specifically, as we describe in Section IV, in recent episodes of monetary tightening the Federal Reserve has relied much less on direct credit actions and has focused instead on the movement in interest rates. It is this change in the behavior of the Federal Reserve that we believe mainly accounts for any lessening of the credit component of monetary transmission. 


\section{NARRATIVE EVIDENCE}

\section{A. Overview}

Much can be learned about the transmission mechanism by looking at the response of the economy to identifiable monetary contractions. In previous work (Romer and Romer, 1989, 1992), we identified seven episodes in which the Federal Reserve moved to reduce inflation and appeared willing to accept the output sacrifices necessary to do so. The dates of these seven monetary policy shocks, which we identified from both the published accounts of the decisions of the Federal Open Market Committee and, when available, the Minutes of the FOMC Meetings, are October 1947, September 1955, December 1968, April 1974, August 1978, October 1979, and December 1988. In addition to these episodes, there are other times in which the Federal Reserve sought to counteract fiscal stimulus and hold inflation steady in response to significant inflationary pressures. The most important of these episodes occurred in March 1959 and December 1965.

In all of these nine episodes interest rates clearly rose. This can be seen in Chart 1, which shows a graph of the three-month Treasury bill rate. ${ }^{3}$ The dates of contractionary monetary policy shocks are marked with solid vertical lines and the dates of the two less severe monetary tightenings are marked with dashed vertical lines. While there is obviously considerable variation in the size of the interest rate movements, in all episodes the threemonth Treasury bill rate rose substantially. On average over the nine episodes, the highest Treasury bill rate during the six months after the shock was 213 basis points more than the lowest rate during the six months before the shock. Other interest rates, such as the federal funds rate, the

3 The data on the Treasury bill rate are from the Citibase databank, April 1993 update. 
commercial paper rate, and the corporate bond rate, show the same consistent rises in the episodes.

This rise in interest rates after monetary contractions is a fundamental component of monetary transmission. In a previous paper (Romer and Romer, 1990), we argue that the "interest rate channel" of the transmission mechanism is the most significant way in which decisions by the Federal Reserve affect the real economy. This suggests that in contemplating recent changes in the financial system, an important question to ask is whether any of the changes have altered the ability of the Federal Reserve to affect interest rates. While we analyze this question in more depth in Section IV, Chart 1 shows that there has been no obvious change in the ability of the Federal Reserve to control short-term rates. It may have taken larger or smaller movements in reserves to achieve a certain movement in interest rates in various eras, but the empirical evidence clearly suggests that the Federal Reserve has consistently been able to make rates move.

As discussed above, monetary contractions may raise the cost of funds to banks beyond their effect on the general level of interest rates. This direct effect on banks is the piece of the transmission mechanism that is most often thought to be affected by the increasing diversification and deregulation of the American financial system. To understand why effects on banks' ability to lend are a component of the transmission mechanism, and especially how the transmission mechanism may have been affected by recent changes in financial markets, we consider each of the episodes of tight monetary policy in turn. We begin with the periods of tight policy from the 1966 "credit crunch" to the 1980 credit controls, since these illustrate banks' flexibility and the Federal Reserve's reliance on direct credit actions most clearly. We then describe the episodes of tight policy in the early postwar years. The discussion of the most recent episodes of tight 
policy is deferred to Section IV, where we consider recent changes in the transmission mechanism.

\section{B. Episodes, 1965-1980}

This section discusses the major episodes of tight monetary policy in the 1960s and 1970s. ${ }^{4}$ We argue that the limitations on intermediaries' ability to lend that arose in these periods were largely the result of direct actions by the Federal Reserve and of particular regulations (notably Regulation Q). In the absence of these actions and regulations, intermediaries would have had sufficient flexibility in their portfolios and in their ability to raise funds to avoid sharp reductions in lending.

1965. The first episode of restrictive policy we consider is the 1966 "credit crunch." The Federal Reserve shifted to tighter policy in 1965 in response to expansionary pressures caused by the Vietnam War, the 1964 tax cut, and high investment spending. The federal funds rate, shown in Chart 2 with the dates of monetary contractions and tightenings marked with vertical lines, rose from $4.01 \%$ in September 1965 to a peak of $5.77 \%$ in November 1966..$^{5}$ As described in the 1967 Economic Report of the President (p. 55), banks

4 Our accounts of the episodes are based on the Economic Report of the President and the Federal Reserve Bulletin for the relevant years, Burger (1969), Monhollon (1970), Wojnilower (1980), Schreft (1990), and Owens and Schreft (1993).

5 The federal funds rate data from 1955 to 1992 are from the Citibase databank, April 1993 update. The data for 1952 through 1954 are deduced from a graph presented in Martens (1958, Exhibit 16, p. 99). The graph is attributed to Garvin, Bantel, and Co., which was the largest federal funds broker in the 1950s. For 1955, the first year for which published data are available, the numbers deduced from the graph are always within 2 basis points of the Citibase data. 
obtained additional loanable funds by increasing their borrowings from the Federal Reserve, reducing their investments in securities, bringing back funds from foreign branches, and attracting additional time deposits through higher interest rates [particularly on negotiable CD's and savings certificates]. As a result, they were able to expand business loans at an annual rate of about 20 percent in the first half of 1966.

Over the course of 1966, the Federal Reserve's concern about the rapid growth of lending, falls in the prices of state and municipal securities resulting from banks' reductions of their security holdings, and the outflow of funds from thrifts to banks caused it to adopt increasingly strong measures aimed at restricting lending. Early in the year, the System began to exert moderate direct pressure on banks to reduce their lending. It allowed the existing Regulation $Q$ interest rate ceiling to become binding in July 1966; the System's reason for not raising the ceiling was specifically to reduce banks' ability to make business loans (Monhollon, 1970; Burger, 1969). In addition, the Federal Reserve, the Administration, and Congress acted to lower the maximum interest rates on certain types of bank liabilities in July and again in September. To further limit banks' ability to raise funds, the Federal Reserve raised reserve requirements on time deposits in July and September, and made short-term promissory notes subject to reserve requirements and Regulation $Q$ in September. Finally, the System stepped up its direct pressure on banks to reduce their lending, culminating in its well known September 1 letter. The letter stated in part:

The System believes that the national economic interest would be better served by a slower rate of expansion of bank loans to business ... . Further substantial adjustments through bank liquidation of municipal securities or other investments would add to pressures on financial markets. Hence, the System believes that a greater share of member bank adjustments should take the form of moderation in the rate of expansion of loans, and particularly business loans. 
Accordingly, this objective will be kept in mind by the Federal Reserve Banks in their extensions of credit to member banks through the discount window.

Owens and Schreft (1993) conclude, based on contemporary banking industry sources, that the Federal Reserve's pressure had a substantial impact on lending.

1968-1969. The Federal Reserve's next shift toward tighter policy began in late 1967. The federal funds rate rose from a low of $3.79 \%$ in July 1967 to a high of $9.19 \%$ in August 1969. Regulation Q became binding in November 1968. Banks displayed even more flexibility than in the 1966 episode in responding to the resulting outflow of funds: they reduced their security holdings, borrowed heavily in the Eurodollar market, issued new small denomination time deposits, increased their borrowing at the discount window, entered loan repurchase agreements with their borrowers, and issued commercial paper through bank holding companies. The Federal Reserve responded by effectively prohibiting repurchase agreements in August 1969, and by placing reserve requirements on additional Eurodollar borrowings in September. In addition, throughout 1969 there was pressure -- backed by the threat of legislation -- from the Federal Reserve, Congress and the Administration on banks to keep loan interest rates low and to limit their lending. This pressure appears to have prevented banks from raising the prime rate after June 1969 despite large increases in prevailing interest rates. The resulting low rates of return on loans, together with the direct pressure to restrict loan growth, appear to have had a large effect on banks' lending (Owens and Schreft, 1993, and Wojnilower, 1980).

1974. The third episode of tight monetary policy took place in 19731974. The federal funds rate rose from slightly over $5 \%$ in late 1972 to $10.78 \%$ in September 1973; it then declined to 8.97\% in February 1974 before rising to a peak of almost $13 \%$ in July 1974 . Again banks resorted 
to alternative sources of funds to maintain their lending. Most notably, issuance of CD's, which were no longer subject to interest rate ceilings, exploded in 1973 and 1974. Banks also increased their Eurodollar borrowings, reduced their security holdings, and issued commercial paper and variable interest rate bonds through bank holding companies.

Again the Federal Reserve took actions to attempt to limit banks' efforts to maintain their lending. It increased the marginal reserve requirement on large CD's and bank-related commercial paper from $5 \%$ to $8 \%$ in May 1973 and to $11 \%$ in September. These large increases appear to have been the source of the pause in the rise in the quantity of CD's and in bank business lending in late 1973 and the increase in business borrowing through the commercial paper market (Economic Report of the President, 1974). The marginal reserve requirements were lowered to $8 \%$ in December, and during the period of tight policy in 1974 the Federal Reserve does not appear to have made significant direct efforts to discourage bank lending. ${ }^{6}$ Indeed, the difficulties of Franklin National Bank in May and the failure of the German Herstatt Bank in June disrupted the commercial paper market and led to a shift of borrowing toward banks (Federal Reserve Bulletin, August 1974). The only notable direct disruptions of lending by intermediaries in 1974 appear to have been in the mortgage market, where state usury ceilings were binding in many states.

6 The Federal Reserve did issue two letters to banks about their lending activities during this period, one in April 1973 expressing "concern" about "the heavy volume of bank loan commitments to commercial and industrial companies and financial institutions" and one in September 1974 urging banks to respond to the tight money market conditions by "selecting carefully and responsibly the uses to which they put their loanable funds" (Federal Reserve Bulletin, April 1973, p. 313, and September 1974, pp. 679-680). The letters were not strongly worded, however, and contemporary observers do not cite them as having had significant impacts on banks' behavior. 
1978-1980. The final episode we consider in this section is 19781980. The Federal Reserve shifted to an anti-inflationary policy in 1978, and then dramatically strengthened this policy in October 1979. The federal funds rate rose from slightly under $7 \%$ in early 1978 to $11.43 \%$ in September 1979; after the October policy shift, it rose rapidly to $17.61 \%$ in April 1980. Even more so than in the previous episodes, both banks and thrifts were able to resort to a variety of means of continuing to finance their lending, including CD's, money market certificates, NOW and ATS accounts, repurchase agreements, reduced security holdings, and Eurodollar borrowings. As a result, lending continued to grow rapidly in the first three quarters of 1979, and financial intermediaries' share in total lending actually rose during this period (Economic Report of the President, 1980).

Once again, however, the Federal Reserve took direct action to restrict lending. In conjunction with its change in operating procedures in October 1979, the System established a marginal reserve requirement for member banks of $8 \%$ for large CD's, Eurodollar borrowings, repurchase agreements, and borrowings in the federal funds market from lenders not subject to the reserve requirement. More important, at the direction of President Carter, the Federal Reserve instituted formal credit controls in March 1980. The control program had a variety of parts, including a broadening and a further increase to $10 \%$ in the marginal reserve requirement on managed liabilities, restrictions on overall loan growth, and reserve requirements on increases in consumer loans; many of the provisions applied to non-depository lenders as well as to banks (see Schreft, 1990, for a more complete description). Finally, the high interest rates again caused 
state usury laws on consumer loans to become binding in many states. ${ }^{7}$ Thus, as in the earlier episodes, the restrictions on intermediaries' ability to lend in this episode appear to have arisen primarily from direct Federal Reserve actions and particular regulations, not from general features of monetary policy and the financial system.

\section{Episodes, 1947-1964}

This section discusses the major episodes of tight monetary policy in the 1940s and 1950s. ${ }^{8}$ We find that in all of these episodes banks sought to maintain lending by selling off government securities at rapid rates. In 1947 the Federal Reserve intervened to restrict lending directly, while in both 1955 and 1959 the Federal Reserve appears to have let interest rates be the only mechanism for restraining credit creation.

1947. In October 1947 the Federal Reserve moved to stem the high rate of inflation that accompanied the return to peacetime consumer spending patterns. Among the actions taken in late 1947 and early 1948 were a small rise in the discount rate and an agreement with the Treasury to allow the rate on short-term government securities to rise from its low pegged level (though the rate on long-term government bonds remained fixed). The immediate response of the banking system to the contractionary policy was to sell off some of its vast holdings of wartime government debt in order to maintain lending. These sales, coupled with an inflow of gold from abroad, caused the monetary contraction to have little immediate

7 State usury ceilings were also often binding on mortgage rates in 1979; these ceilings were overridden by Federal legislation at the end of the year, however.

8 Our accounts of these episodes are based on the Economic Report of the President and the Federal Reserve Bulletin for the relevant years, and Wojnilower (1980). 
impact on bank lending.

As in the contractionary episodes of the later postwar era, the Federal Reserve responded to evidence of flexibility in the banking system by taking additional measures to restrict lending directly. In a joint statement issued on November 24, 1947, the Federal Reserve, the Comptroller of the Currency, the FDIC, and the National Association of Supervisors of State Banks urged bankers to "exercise extreme caution in their lending policies" (Federal Reserve Bulletin, December 1947, p. 1465). Further weight was given to the call for voluntary credit restraint by a proposal submitted to Congress by Federal Reserve Chairman Mariner Eccles for a special temporary reserve requirement, held in the form of government securities, of an additional $25 \%$ on demand deposits (Federal Reserve Bulletin, January 1948, p. 14).

The most substantive action taken to restrain credit was directed not against business loans but against consumer installment credit. In August 1948, the Federal Reserve convinced Congress to reimpose the restraints on consumer installment loans that had existed during the war (though in a somewhat more lenient form than in the early 1940s). These restraints, which became effective in September 1948, set minimum down payments and maximum maturities for installment loans. They are cited by the Federal Reserve as an important cause of the leveling off in the growth of installment credit in the fourth quarter of 1948 (Federal Reserve Bulletin, April 1949, p. 336).

1955. In late 1955 the Federal Reserve again became concerned about the current level of inflation and moved to a more restrictive monetary stance. The discount rate was raised four times in 1955 and the FOMC authorized contractionary open-market operations. This switch to tighter policy is clearly evident in both the federal funds rate, which increased by over 100 basis points during 1955 , and the rate on short-term 
government securities, which increased by roughly 150 basis points in the same period. Short-term rates continued to rise in 1956 and early 1957, with the T-bill rate reaching a peak value of $3.59 \%$ in October 1957.

As in 1947, banks responded to the pressure on reserves caused by the contractionary open-market operations by selling off government securities in record amounts. Bank holdings of government securities declined nearly 11 percent in 1956 . This reduction in investments allowed banks to maintain loans to businesses. In contrast to its behavior in 1947 and in the later episodes, the Federal Reserve took no additional actions to restrict credit during the 1955 episode. Indeed, in January 1957 the Federal Reserve raised the Regulation $Q$ ceiling on the maximum interest rate payable on time deposits, apparently to prevent a squeeze on bank lending (Federal Reserve Bulletin, February 1957, p. 123). Testimony by Federal Reserve Chairman William McChesney Martin in February 1957 shows that the Federal Reserve was very willing to allow allocation by price and actively opposed direct credit restrictions. In response to the question "Is there any acceptable way of restraining the demand for loans without raising interest rates?" Martin answered:

Essentially, the problem is one of rationing, and involves many of the same sorts of difficulties and problems that have attended such programs in other areas. In a peacetime economy there is no acceptable way of administratively determining who is to be permitted to borrow and who is to be forbidden.... An attempt to develop any system of general administrative rationing of credit would ... create inequities ... [and] would tend to undermine the flexible and progressive character of our economy (Federal Reserve Bulletin, February 1957, p. 150, emphasis in the original).

In June 1957 the Board of Governors also issued a statement declaring that "a special peacetime authority to regulate consumer instalment credit is not now advisable" (Federal Reserve Bulletin, June 1957, p. 648). 
1959. The recovery from the 1957-1958 recession was sufficiently rapid that the Federal Reserve became concerned about inflation late in 1958. However, in this instance, the Federal Reserve was not sufficiently concerned about inflation that it was willing to accept output losses to reduce it. Rather, in 1958 and 1959 it took actions only to prevent the expansion from becoming too brisk. In both August and October 1958 the Federal Reserve raised the discount rate (Federal Reserve Bulletin, February 1959, pp. 107-108). In early 1959 the Federal Reserve began contractionary open-market operations and in March 1959 imposed the first of three additional increases in the discount rate. (Economic Report of the President, 1960 , p. 44). The federal funds rate rose from $0.68 \%$ in July 1958, when the Federal Reserve was working to end the recession, to $2.80 \%$ in March 1959, when it was seriously trying to limit expansion. The federal funds rate continued to rise during 1959 , peaking in November at $4.0 \%$.

Banks responded to the contraction in reserves by once again selling off short-term government securities. Commercial bank holdings of government securities declined 16\% between 1958 and 1960 and "at the end of 1959, the ratio of bank holdings of Government securities to total deposits was the lowest since before World War II" (Federal Reserve Bulletin, February 1960, p. 122). As in 1955, the Federal Reserve appears to have been willing to let banks maintain lending and rely only on the rise in interest rates to restrict credit creation. Chairman Martin testified in February 1960 that:

The task of supplying this huge demand for credit without severe inflationary consequences has been accomplished chiefly by the sound and democratic process of letting those who would borrow provide those who would save with an inducement to risk voluntarily the loan of their savings (Federal Reserve Bulletin, February 1960, p. 126).

No direct controls on credit were ever issued, and with the slowdown in 
economic activity in the middle of 1960 the Federal Reserve switched from contractionary to expansionary policy.

\section{STATISTICAL EVIDENCE}

The preceding section provides narrative evidence that the disruptions of bank lending associated with postwar monetary contractions were largely the result of deliberate actions by the Federal Reserve. In this section we examine whether this conclusion is consistent with the behavior of two indicators of credit market conditions: the spread between the prime bank loan rate and the commercial paper rate, and the mix of credit outstanding between bank loans and commercial paper. We find that there is a systematic relationship between credit actions and these indicators, and that the credit actions account for an important part of the relationship between monetary policy and the indicators.

This section also examines whether Federal Reserve credit actions have a significant impact on industrial production. We find that they appear to have a moderate effect on real output when the general stance of monetary policy is controlled for, but that these effects are measured imprecisely.

\section{A. The Mix and the Spread}

Kashyap, Stein, and Wilcox (1993) point out that to examine the relative availability of bank and non-bank lending, one can examine either relative quantities or relative prices. If monetary policy actions force banks to reduce their lending, bank loans will fall and firms that are able to will turn to alternative sources of finance. Kashyap, Stein, and Wilcox therefore use the mix of external finance, which they define as the ratio of bank loans 
outstanding to the sum of bank loans and commercial paper outstanding, as an indicator of restrictions on banks' ability to lend. Similarly, if some businesses can only borrow from banks, then the spread is likely to rise if bank lending is restrained more than other types of lending.

The mix and the spread are, however, imperfect indicators of banks' ability to lend. Firms that depend on banks for funds are generally riskier than firms that issue commercial paper. Thus bank loans may fall relative to commercial paper in response to tight monetary policy not because banks have difficulty in obtaining funds, but because lenders do not wish to lend to relatively risky firms in times when interest rates are high and the economy is weakening. Indeed, Gertler and Gilchrist (1993) and Oliner and Rudebusch (1993) show that most of the response of the mix to tight monetary policy documented by Kashyap, Stein, and Wilcox reflects a shift in lending by all types of lenders away from small firms (which are largely bank-dependent) toward large firms (which are much less bank-dependent). This component of movements in the mix does not reflect a differential impact of monetary policy on banks' ability to obtain funds. Similarly, some portion of the response of the spread to monetary policy presumably simply reflects the fact that tight policy increases the riskiness of bank loans relative to commercial paper.

Charts. Despite these limitations, it is still instructive to see what happens to the spread and the mix after the Federal Reserve credit actions described in Section II. Chart 3 shows the quarterly spread from 1947 to 1992. ${ }^{9}$ The vertical lines denote the dates at which the Federal Reserve

9 The spread is calculated as the difference between the prime rate charged by banks on short-term business loans and the rate on six-month commercial paper. The data are from the Citibase databank, April 1993 update. Quarterly interest rates are calculated as the average of monthly observations. We use quarterly data, even though monthly data are 
began to interfere directly in the provision of bank credit. We date the starts of the credit actions (in quarters) as 1966:3, 1969:3, 1973:2, and 1979:4. As described above, the Federal Reserve also undertook some credit actions in September 1948. However, because the most significant of those actions, the restrictions on installment credit, were directed at consumer loans, one would not expect a large impact on business lending. For this reason, we exclude the 1948 action from the analysis of the mix and the spread. We do, however, include it in the analysis of the effect of credit actions on industrial production.

The response of the spread to the credit actions is truly remarkable. In all four instances the spread rose substantially within a year of the action. There is, however, a noticeable variation in the size and timing of the change. In 1966 the spread rose from roughly zero at the time of the action to 0.78 three quarters later; in 1979 it rose from 1.98 at the time of the action to 5.57 just two quarters later. In 1969 the spread was negative for three quarters after the credit action because banks, under threat of legislation, did not increase the prime rate as other rates rose. However, even in this instance the spread rose by more than a point in late 1970, presumably as soon as the threat abated.

From the chart it is clear that Federal Reserve credit actions are not the only source of movements in the spread. For example, in both 1954 and 1958 the spread jumped by roughly a point. Based on timing, the Federal Reserve's shift to anti-inflationary policy in late 1955 does not appear to be a candidate explanation for these rises. This is consistent with the view that credit market disruptions are the result of direct credit market actions and other shocks, not a by-product of general monetary tightening.

available, to maintain consistency with the mix data, which are only available quarterly. 
Chart 4 shows the quarterly mix of external finance for 1952 to 1992. ${ }^{10}$ Once again, the dates of Federal Reserve credit actions are shown by vertical lines. The behavior of the mix is somewhat hard to discern because it has a strong downward trend since the mid-1960s. However, it is certainly the case that the mix declines after each of the credit actions in the postwar era. The decline is most noticeable after the action in 1973, when the mix changes abruptly from rising to falling, and after the action in 1979 , when the mix falls rapidly from a level base. As with the spread, the mix moves very little during the monetary contractions of 1955 and 1959. This is consistent with our narrative evidence that the Federal Reserve did not take direct actions in these episodes to restrict banks' business lending. Regressions with Dummy Variables. The behavior of the spread and the mix shown in Charts 3 and 4 is consistent with the view that Federal Reserve credit actions cause disruptions in bank lending. However, it is useful to supplement these charts with more formal statistical tests of the effect of credit actions on these indicators of bank lending. To test for the effect of monetary policy on the spread and the mix, Kashyap, Stein, and Wilcox (1993) regress the change in the spread or the mix on several own lags and several lags of the Romer and Romer dummy variable for the dates of Federal Reserve switches to anti-inflationary monetary policy. This same framework can be used to analyze the effects of credit actions by replacing

10 Following Kashyap, Stein, and Wilcox (1993), we use data on the mix from the Federal Reserve Board's flow of funds accounts. The loans series is the sum of bank loans not elsewhere classified in the nonfarm, noncorporate business sector and in the nonfinancial corporate business sector. The commercial paper series is total nonfinancial corporations' commercial paper outstanding. The data are from the Federal Reserve's flow of funds database and are available from 1952:1 to 1992:4. The data are described in the Introduction to Flow of Funds, Board of Governors (1980a). The mix is multiplied by 100 to convert it to percent. 
the monetary policy variable with a dummy variable for credit actions.

Lines 1 and 7 of Table 1 essentially replicate the Kashyap, Stein, and Wilcox results. Like them, we regress the change in the spread and the change in the mix, respectively, on eight own lags and eight lags of the Romer and Romer monetary policy dummy variable over the sample period 1964:1 to $1989: 4^{11}$ All the data are quarterly. We use the regression results to compute the cumulative impulse response function of the left-hand side variable (either the spread or the mix) to the monetary policy dummy. The table reports the level of the impulse response function and the associated t-statistic for the quarter of maximum statistical significance over the first eight quarters after the shock to the policy dummy. ${ }^{12}$ Consistent with Kashyap, Stein, and Wilcox's results, we find a large and highly significant association between monetary policy shifts and the spread and the mix. The estimated peak responses are a rise of 1.89 percentage points in the spread and a decline of 2.64 percentage points in the mix.

Extending the Kashyap, Stein, Wilcox sample period to cover as much of the postwar era as data availability allows [see Lines 2 and 8]

11 We also include a constant in all regressions. Following Kashyap, Stein and Wilcox, we do not include either a trend or seasonal dummy variables in the regressions. The regressions are not identical to Kashyap, Stein, and Wilcox's because we update the list of contractionary monetary policy shocks to include the 1988:4 episode. However, inclusion of the 1988 shock changes the results only slightly.

12 As described in the notes to Table 1, in all cases but two the highest statistical significance of the effect of the monetary policy dummy occurs after seven quarters; in the remaining two cases, the impulse response is slightly more significant after two quarters. To make the results for the level of the impulse response function comparable across regressions, for these two cases we report the cumulative impulse response and $t$-statistic after seven quarters rather than after two. 
changes the results somewhat. ${ }^{13}$ For the spread, including the 1950 s reduces the estimated impact of the monetary policy dummy variable by about a third and reduces the significance level somewhat. For the mix, expanding the sample period reduces the impulse response function by about $10 \%$, though it raises the significance level slightly. The fact that expanding the sample period reduces the impulse responses to the monetary policy dummy variable in both cases is consistent with Charts 3 and 4, which show that neither the spread nor the mix moved much in response to the monetary policy shock in 1955.

To see if credit actions are important to the behavior of the spread and the mix, we redo the Kashyap, Stein, Wilcox regressions with eight lags of a dummy variable for the onset of Federal Reserve credit actions. As shown in Charts 3 and 4, the quarterly dates of the actions are 1966:3, 1969:3, 1973:2, and 1979:4. However, because the credit action in 1969 took the form of restrictions on the prime rate, we exclude the 1969 date from the spread regression. ${ }^{14}$ We run this regression both over the shorter Kashyap, Stein, Wilcox sample of 1964-1989 and over the longer period of 1954-1992.

The results in Lines $3,4,9$, and 10 of Table 1 show that the credit action dummy variable has a great deal of predictive power. When it is included in place of the monetary policy dummy, the impulse responses for

13 The flow of funds data on the mix begin in 1952:1, so the earliest starting date for the mix regression is 1954:2. We use this sample period for the spread as well. Since consistent data on the spread are available starting in 1947, the longer sample period 1949:2 to 1992:4 can also be used for the spread regressions. The results for this longer sample are similar to those for the sample starting in 1954.

14 Including 1969 in the list of credit actions does not change the regression results for the spread appreciably. 
both the spread and the mix regressions are of the expected sign and highly statistically significant. For the shorter sample, the point estimates imply that a credit action is followed by a rapid rise in the spread of 1.78 percentage points after two quarters and 1.96 points after seven, and by an equally rapid decline in the mix of 1.92 percentage points after two quarters and 2.37 points after seven. The point estimates of the effects of credit actions are virtually unchanged in the longer sample for both the spread and the mix, but the significance levels are higher.

Because credit actions typically accompany general monetary contractions, it is more interesting to investigate the effects of credit actions controlling for the general tenor of monetary policy. Lines 5 and 11 show the results of the regression including both variables for the shorter sample period and Lines 6 and 12 show the results for the combined regression over the longer sample period. In the regressions including both dummy variables, the estimated impacts of credit actions on both the spread and the mix remain large and highly significant. Thus the regressions suggest that the movements in the spread and the mix following the credit actions reflect disruptions of bank lending stemming from these actions, rather than effects of the overall monetary policy tightenings that generally occur around the same times.

In addition, the credit action variable takes away a considerable part of the explanatory power of the monetary policy variable. For both the spread and the mix, the impulse responses to the monetary policy dummy fall by about a quarter when the credit action dummy is included. If one accepts Gertler and Gilchrist's and Oliner and Rudebusch's evidence that the majority of the overall relationship between the monetary policy shifts and the mix is due to compositional effects rather than to changes in banks' ability to lend, the results here for the mix leave only a small portion of the 
relationship to be explained by a bank credit channel. ${ }^{15}$ We do not have quantitative estimates of the extent to which the overall link between monetary policy and the spread is driven by changes in the relative riskiness of bank loans. However, if the results for the mix are indicative of the sources of movement in the spread, the relationship between monetary policy and the spread would also for the most part not reflect a credit channel of monetary transmission. ${ }^{16}$

Charts 5 and 6 plot the estimated cumulative impulse response functions, along with the associated one standard error bands, of the spread and the mix to the monetary policy dummy and the credit action dummy implied by the regressions with both variables for the full sample period (Lines 6 and 12 of Table 1). The time patterns of these impulse responses are representative of those implied by the other regressions in the table. For the general monetary policy shift, the estimates imply a gradual response of both the spread and the mix. This could be consistent with the

15 A natural test of this interpretation of the results would be to investigate the relationship between movements in Oliner and Rudebusch's "composition-adjusted" mix and monetary policy shifts and credit actions. Unfortunately, there has been only one credit action since the inception of the data on small and large firms employed by Oliner and Rudebusch and Gertler and Gilchrist. Thus this test is not feasible.

16 Following Kashyap, Stein, and Wilcox, we exclude the contemporaneous value of the monetary policy and credit action dummy variables. However, the results are robust to their inclusion. In the regression for the spread including both explanatory dummy variables and run over the longer sample period, the cumulative impulse response function at the point of maximum significance is 0.78 [ $\mathrm{Lag} 7]$ with a t-statistic of 2.04 for the monetary policy variable and 1.44 [Lag 2] with a t-statistic of 3.83 for the credit action variable. In the regression for the mix including both explanatory dummy variables and run over the longer sample period, the cumulative impulse response function at the point of maximum significance

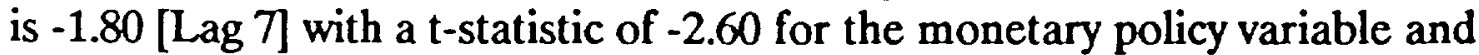
-1.56 [Lag 2] with a t-statistic of -2.75 for the credit action variable. 
notion that monetary tightening affects credit markets by gradually affecting the creditworthiness of borrowers. For the credit actions, in contrast, the results suggest a very sharp response of both the spread and the mix after two quarters, a considerable reversal of the initial effect over the next two quarters, and then a gradually increasing effect over the second year. These results, particularly the rapid strong effects and the quick rebound, are consistent with the narrative evidence of the previous section that the actions caused immediate but short-lived disruptions of bank lending. ${ }^{17}$

Regressions with Interest Rates. Kashyap, Stein, and Wilcox also consider regressions of the change in the spread and in the mix on eight own lags and eight lags of the change in the federal funds rate. This follows the work of Bernanke and Blinder (1992), who argue that the federal funds rate is the best continuous indicator of the stance of monetary policy. Table 2 therefore presents regression results using the change in the federal funds rate in place of the monetary policy dummy variable. For comparability with the other results, we compute the implied impulse responses of the spread and the mix to the average rise in the funds rate during the episodes of general monetary policy tightening. Specifically, the average across the six episodes of general tightening since 1954 of the difference between the

17 The findings in Table 1 may account for the puzzling behavior of measures of the importance of the credit channel of monetary policy documented by Miron, Romer, and Weil (1993). Miron, Romer, and Weil show that financial market flexibility has been increasing over the twentieth century and that the importance of banks does not show a pronounced upward trend. Thus one would expect the credit channel to be declining in importance. But standard indicators of the credit channel (such as the spread and the mix) in fact exhibit much larger movements in the episodes of tight monetary policy in the period 1960-1980 than in the episodes in other periods during the century. Our findings suggest that these anomalous results may be due to the fact that the movements in the 1960-1980 episodes are partly the result of direct credit actions rather than of a credit channel of open-market operations. 
lowest value of the funds rate in the two quarters before the policy shift and the highest value in the two quarters after is 2.84 percentage points; we therefore find the impulse responses to a 2.84-percentage-point shock to the funds rate.

Lines 1 and 7 replicate Kashyap, Stein, and Wilcox's finding that there is a highly significant relationship between the federal funds rate and both the spread and the mix. Lines 2 and 8 show that extending the sample period reduces the impulse response functions slightly. Lines $3,4,9$, and 10 replace the funds rate with the credit action dummy; these regressions are the same as those reported in the corresponding lines of Table 1.

Lines $5,6,11$, and 12 include both the funds rate and the credit action dummy. We view these regressions as providing a lower bound on the effects of credit actions relative to general monetary policy shifts: general monetary policy is measured by a continuous (and at times surely endogenous) indicator of monetary policy for the full sample, while credit actions are measured solely by a dummy variable for just four dates (three for the spread). Nonetheless, the results suggest a large and significant link between credit actions and the spread and the mix. The results for the full sample suggest that the impact of a credit action on the spread after two quarters is as large as the maximum effect of a shift of six percentage points in the federal funds rate. For the mix, the estimated effect after two quarters as large as the maximum effect of a four-percentage-point change in the funds rate. In all cases, the estimated maximum effect is strongly significant. In addition, inclusion of the credit action dummy again reduces the estimated effect of the indicator of general monetary policy; the estimated effect of the funds rate on both the spread and the mix falls by 
about a fifth. ${ }^{18}$

Charts 7 and 8 show the cumulative impulse responses and one standard error bands of the spread and the mix to a rise of 2.84 percentage points in the funds rate and to the credit action dummy for the regressions including both variables and run over the full sample. Again, the patterns of the impulse responses are representative of those for the other regressions. The only notable difference between these impulse responses and those shown in Charts 5 and 6 is that the response of the mix to the funds rate is essentially complete in three quarters rather than occurring gradually over seven, as it does in response to the monetary policy dummy.

Taken together, the regression results confirm the narrative evidence of the previous section that Federal Reserve credit actions cause important disruptions of bank lending. The regressions' implications for the credit channel of monetary transmission are complicated by the likely impact of general tightening on the spread and the mix through mechanisms other

18 Including the contemporaneous values of the federal funds rate and the credit action dummy variable changes the regression for the spread somewhat. Because there is one month in early 1980 when the federal funds rate skyrockets and the spread falls, the impulse response function for the spread has an extreme saw-tooth pattern. Despite this feature, the credit action dummy variable retains most of its predictive power. In the regression run over the longer sample period and including both variables, the cumulative impulse response function at the point of maximum significance is 0.30 [Lag 1] with a t-statistic of 1.94 for the change in the federal funds rate and 0.95 [Lag 2] with a t-statistic of 2.45 for the credit action variable. For the mix, including the contemporaneous values of the explanatory variables has little effect. In the regression for the mix including both explanatory variables and run over the longer sample period, the cumulative impulse response function at the point of maximum significance is -0.86 [Lag 3] with a t-statistic of -3.26 for the change in the funds rate and -1.17 [Lag 2] with a t-statistic of -1.93 for the credit action variable. While this robustness is reassuring, we feel that including contemporaneous values of the federal funds rate is highly questionable because there is such a large endogenous component in its movements over short horizons. 
than a credit channel. The results are certainly consistent with the narrative evidence indicating that banks have generally found ways of avoiding restrictions on their ability to obtain funds in the face of tight policy; they are not, however, decisive on this point.

\section{B. Industrial Production}

Even if credit actions do affect bank lending, there remains the question of whether disruptions in bank lending affect real output. To analyze this question, we examine how industrial production responds to credit actions. ${ }^{19}$ Chart 9 graphs the monthly Federal Reserve Index of Industrial Production (in logarithms) with the dates of credit actions shown with vertical lines. ${ }^{20}$ For this analysis we include the credit action in September 1948. While the consumer credit controls in this episode would not be expected to affect the mix and the spread, they should affect consumer spending and hence output. ${ }^{21}$ Chart 9 suggests that there is certainly a correlation between credit actions and declines in real output: after every credit action industrial production declines noticeably within two years.

As with the previous analysis of the mix and the spread, however, it is important to supplement simple charts with regression analysis. In

19 We are grateful to Benjamin Friedman and Mark Gertler for suggesting that we include the output analysis in the paper. Our approach is similar to that suggested by Owens and Schreft (1993).

20 We seasonally adjust this series by regressing it on a linear trend, a constant, and eleven monthly dummy variables. The seasonally unadjusted index was provided to us by the Board of Governors of the Federal Reserve System.

21 The monthly dates of the other credit actions are 1966:7, 1969:8, 1973:5, and 1979:10. 
Romer and Romer $(1989,1992)$ we test the impact of contractionary monetary policy on real output by regressing the monthly change in industrial production on 24 own lags and the contemporaneous value and 36 lags of the dummy variable for Federal Reserve switches to anti-inflationary monetary policy. ${ }^{22}$ This same framework can be used to test the effect of credit actions on industrial production.

Table 3 shows the results of this analysis. As with the regressions for the mix and the spread, we report the cumulative value of the impulse response function at the point of maximum significance. Line 1 simply replicates our previous monetary policy regressions. It suggests that a switch to anti-inflationary monetary policy causes industrial production $\mathbf{3 0}$ months later to be $11 \%$ lower than it otherwise would have been. This decline is highly statistically significant.

Line 2 shows that when the credit action dummy variable is substituted for the monetary policy variable in the regression, the most significant impact is felt just 9 months later. This suggests that direct credit actions have a much more rapid effect on output than does general monetary tightening. The quantitative effect, however, is noticeably smaller than that of the monetary policy dummy variable: a credit action reduces industrial production 9 months later by roughly $6 \%$ relative to what it otherwise would have been. This decline is statistically significant at the $98 \%$ level.

Because credit actions and general monetary tightening typically occur together, the more interesting question is what the effects of credit actions are, taking into account monetary policy. Line 3 shows the results

22 Because the industrial production series that we use in the regression is not seasonally adjusted, we also include a constant and eleven monthly dummy variables. 
of including the contemporaneous value and 36 lags of both the monetary policy dummy and the credit action dummy. Chart 10 shows the impulse response functions with one standard error bounds for both variables. The impact of the monetary policy variable is essentially unaffected by the inclusion of the credit action variable: the cumulative impact remains large and highly statistically significant. The point estimate of the impact of the credit action dummy variable, however, is reduced by almost a third: the cumulative impact of a credit action at the point of maximum significance is now $-4.2 \%$. This effect is statistically significant at slightly less than the $90 \%$ confidence level.

The point estimates from this regression suggest that credit actions have a moderate effect on industrial production. However, the fact that the effect of credit actions is not statistically significant at conventional levels indicates that there is substantial uncertainty about the importance of the bank credit side of the transmission mechanism: the actual effect could be either substantially larger or trivial. At the same time, the fact that monetary policy actions do have a very large and significant impact on industrial production suggests that some part of the transmission mechanism, most likely the interest rate side, is quantitatively very important.

\section{THE IMPACT OF FINANCIAL INNOVATION}

The narrative analysis of the postwar transmission mechanism suggests that even before the recent changes in financial markets, the American financial system was remarkably flexible. In nearly every episode of contractionary monetary policy that we examine, banks sought and found innovative ways to raise funds and maintain lending. Both the narrative and statistical evidence suggest that to the extent that credit market disruptions 
occurred, it was because the Federal Reserve stepped in to prevent such innovation. Thus, the credit side of the transmission mechanism throughout the postwar era has been largely the result of deliberate Federal Reserve actions, not the consequence of a special link between bank lending and monetary policy. The evidence also indicates that the interest rate component of monetary transmission has been remarkably stable over time. Despite the flexibility of the postwar American financial system, the Federal Reserve has consistently been able to raise interest rates when it felt conditions warranted.

This description of the transmission mechanism provides important perspective on the likely impact of the recent financial innovations. If the American financial system was already very flexible, then the recent changes would transform the transmission mechanism only if they fundamentally altered one of the channels by which Federal Reserve actions affect the economy. In particular, as long as the Federal Reserve can still affect interest rates and can still restrict lending directly through persuasion and regulatory changes, the recent changes should not lead to major changes in the transmission of monetary policy.

\section{A. The Interest Rate Side}

If financial innovations were to proceed to the point where bank liabilities subject to reserve requirements coexisted as perfect substitutes with liabilities of non-bank institutions not subject to reserve requirements, monetary policy would lose its power over general interest rates. In such a situation, investors would respond to changes in the supply of reserves simply by shifting their assets between bank and non-bank institutions. The Federal Reserve's only power to influence the economy would be through its ability to affect lending. Some observers have suggested that the U.S. financial system may be moving toward such a situation (for example, 
Bernanke, 1993).

As a practical matter, it is clear that this description does not fit the U.S. economy today. The Federal Reserve is able to use open-market operations to move the federal funds rate quite precisely when it wishes to. Nor should this be surprising. The only plausible case in which bank liabilities subject to reserve requirements and non-bank liabilities not subject to reserve requirements would be perfect substitutes would be when they provided essentially identical services. But since reserve requirements force banks to offer a lower rate of return, in such a situation the non-bank liabilities would dominate the bank liabilities. Thus perfect substitutability would lead not to a loss of Federal Reserve control over interest rates, but to the disappearance of liabilities subject to reserve requirements.

Even the disappearance of such liabilities would not eliminate the Federal Reserve's control over interest rates. Institutions offering transactions deposits and other highly liquid instruments would still need to hold reserves to provide liquidity services; in choosing the quantity of reserves, they would face the usual tradeoff between greater foregone interest from holding more reserves and lower liquidity from holding fewer. Similarly, individuals and firms would still hold currency, and their holdings would be determined by the tradeoff between foregone interest and inconvenience. Thus there would continue to be a demand for high-powered money that varied with prevailing interest rates. The Federal Reserve's control over the supply of high-powered money would therefore continue to give it control over interest rates. It is possible that financial innovations will make the demand for high-powered money less stable, but the Federal Reserve can maintain its control over interest rates in the face of such instability simply by adjusting the supply of high-powered money in response to fluctuations in demand.

Only in the extreme case of a cashless economy would open-market 
operations no longer allow the Federal Reserve to alter interest rates. Although the functioning of an economy without currency is an interesting theoretical subject, it is far from relevant to the U.S. economy. The ratio of currency holdings to GDP, for example, exhibits only a slight downward trend over the past thirty years. Thus, the interest rate channel is not likely to change in the near, or even not-so-near, future.

\section{B. The Credit Side}

For the "credit side" of the transmission mechanism to still be relevant, bank lending must remain important and the Federal Reserve must still have the capacity to affect bank lending directly. In this section, we provide evidence that both of these conditions are satisfied. But we also argue that the evidence from the most recent episodes of tight policy indicates that the Federal Reserve is much less inclined today to intervene directly in credit markets than before. Thus the main change in monetary transmission is not in the characteristics of financial markets, but in the nature of Federal Reserve actions.

Importance of Banks and Federal Reserve Actions. The simplest evidence of banks' continued importance in U.S. credit markets is provided by direct measures of the magnitude of bank lending relative to the size of the economy. Chart 11 plots bank loans to businesses relative to GDP for the period 1952-1992. ${ }^{23}$ The chart shows that although the ratio declined sharply in the 1970s, this decline only partly reversed the spectacular rise in the 1960s. As a result, the ratio of loans to GDP was roughly twice as large in 1980 as in 1960 . There was another dramatic fall in the series in the early

23 The data on bank loans are the same as those used in the calculation of the mix in Section III. Since these data are nominal, we scale them by nominal GDP. The GDP data are from the Citibase databank, April 1993 update. 
1990 s, but this again only partly offset an even larger rise in the 1980s. Thus, according to this measure, bank lending is if anything more important today than in the early postwar era. ${ }^{24}$

Chart 11 almost surely understates the current importance of bank lending. Because banks' off-balance sheet activities have been growing, the ratio of bank loans to the capital stock has become an increasingly inaccurate measure of banks' importance in credit markets. As documented by Boyd and Gertler (1993), banks provide backup lines of credit for almost all of the rapidly expanding commercial paper market (including finance company paper); they provide a growing volume of loan commitments; and they have been increasingly selling and securitizing their loans. A simple indication of the importance of these off-balance sheet activities is that fee income now accounts for about a third of total bank income, up from about a fifth in the late 1970s. After reviewing these trends, Boyd and Gertler (1993, p. 10) conclude that "commercial banks remain involved in virtually all short term working capital lending in the U.S. economy."

While banks remain central to credit allocation, it is reasonable to question whether the Federal Reserve still has the capacity to disrupt lending directly. Its jawboning and other efforts to encourage lending over the past few years do not appear to have had any substantial impact on lending. In addition, interest rate ceilings have been eliminated, and the 1969 Credit Control Act, which provided the legislative authority for some elements of the 1980 credit controls, was repealed effective in 1982.

24 Miron, Romer, and Weil (1993) provide additional evidence of the increasing importance of bank loans over the postwar era. They show that loans are a larger fraction of total liabilities plus equities for corporations in the 1980s than in the 1950s, and that since the mid-1960s the liabilities of unincorporated businesses, which are the firms most likely to have to borrow from banks, have been growing faster than the liabilities of corporations. 
Despite these developments, the Federal Reserve's capacity to disrupt lending remains substantial. Earlier jawboning efforts, in contrast to the recent ones, were backed by implicit or explicit threats of limitations on access to the discount window and of legislative restrictions on interest rates or lending. There is no reason to expect that such threats would not be effective today. In addition, the Federal Reserve maintains its authority to alter existing reserve requirements, or impose new ones, on various classes of bank liabilities. Given the increased competition between bank liabilities and other assets, it is likely that such reserve requirements would have even larger impacts on banks' cost of funds today than before. Thus, the Federal Reserve still has access to most of the tools it used in its previous direct efforts to restrict lending, and those tools are unlikely to have lost their ability to affect banks' lending activities. Given the continued central role of bank lending, we conclude that the Federal Reserve still has the ability to affect credit flows significantly through direct credit actions if it wishes to.

Changes in Federal Reserve Actions. Although the Federal Reserve still has the ability to restrict banks' lending activities directly, in recent episodes of tight monetary policy it has chosen not to do so. There have been two significant episodes of tight monetary policy since 1980 . The first episode occurred in 1981-1982. ${ }^{25}$ After ending the credit control program and allowing interest rates to fall in response to the 1980 recession, the Federal Reserve began to tighten again in late 1980. This tightening was a continuation of the general anti-inflationary strategy the System had adopted in 1978 and 1979. The federal funds rate rose from a low of $9.03 \%$

25 Our accounts of these episodes are based on the Economic Report of the President and the Federal Reserve Bulletin for the relevant years, Owens and Schreft (1993), and Cantor and Wenninger (1993). 
in July 1980 to over $19 \%$ in January 1981; it remained around $15 \%$ through mid-1982.

In contrast to its behavior in many of the earlier episodes, the Federal Reserve took no steps to attempt to restrict lending directly in 19811982. In addition, interest rate regulations, though not entirely eliminated, were much less strict than in preceding decades. As a result, there does not appear to have been any notable direct curtailment of banks' and thrifts' ability to lend in this period. The large changes in interest rates and the introduction of new types of demand and savings deposits led to large variations in the growth rate of core deposits during this period. But intermediaries were able to respond to these variations simply by adjusting their issuance of large CD's (see, for example, the Federal Reserve Bulletin, November 1980, February 1981, May 1981, March 1982, and August 1982).

Our final episode of tight monetary policy is the moderate antiinflationary tightening of 1988 and 1989. The federal funds rate rose from a low of $6.58 \%$ in early 1988 to a high of $9.85 \%$ in early 1989 . As in 1981, the Federal Reserve did not attempt to supplement its tight policy by direct efforts to reduce lending. Indeed, beginning in the second half of 1990 , well after policy had begun to ease, the System attempted to encourage lending.

As others have emphasized (for example, Owens and Schreft, 1993, and Cantor and Wenninger, 1993), the behavior of credit markets in this episode differed fundamentally from their behavior in earlier periods of tight policy. Most importantly for our purposes, banks simply did not attempt to turn to alternative sources of funds to maintain their lending. The most plausible interpretation of banks' behavior, in our view, is simply that a variety of factors largely unrelated to the tightening of policy acted to reduce intermediaries' ability or desire to lend. Among the factors were the overbuilding of commercial real estate in the 1980 s, reduced tax incentives for investment, firms' high debt burdens, tighter capital standards and lower 
levels of capital, the savings and loan crisis, and stricter regulatory oversight. Because of these factors, this episode provides little evidence concerning banks' ability to maintain their lending in the face of tight policy.

An alternative view of the recent episode is that the slowdown in lending was largely the consequence of the tight monetary policy working through the asset side of banks' balance sheets, rather than of these other factors. If this view is correct, recent financial changes -- particularly banks' weakened capital positions -- have created a strong credit channel for monetary policy where there was only a weak one before.

We are highly skeptical of this view, for two reasons. First, a substantial direct impact of the additional factors on bank lending is well documented (see for example Cantor and Wenninger, 1993, and Bernanke and Lown, 1992). Second, and even more tellingly, the view that there is now a strong credit channel implies that the decline of nearly 7 points in the federal funds rate -- almost double the 1988-1989 increase -- should have resulted in a boom in bank lending. Instead bank lending has remained weak.

Whatever one's interpretation of the 1988 episode, it seems clear that the Federal Reserve did not undertake the sort of direct credit actions that were so common in the 1960 s and 1970s. This raises the obvious question of whether the move away from credit actions represents a permanent change or a temporary aberration. Two factors suggest that it might be only temporary. First, the Monetary Control Act of 1980 provided for a multi-year phase-in of new reserve requirements. As a result, it is possible that the Federal Reserve chose not to change reserve requirements in the 1981-1982 monetary tightening simply because it would have been administratively difficult.

More intriguing is the possibility that the use of credit actions may depend on the political climate. Owens and Schreft (1993) show that Wright 
Patman, as chairman of the House Banking Committee, had a significant influence on Federal Reserve policy in the 1960s. Because Patman threatened to legislate credit controls and to urge an antitrust investigation of the setting of the prime rate, the Federal Reserve may have been forced to rely more on direct credit actions than it otherwise would have. Similarly, the impetus for the 1980 credit controls clearly came from the Carter administration rather than from the Federal Reserve. ${ }^{26}$ One interpretation of these facts is that the Federal Reserve employs credit actions when it feels constrained by political forces from raising interest rates. This interpretation is consistent with the fact that the four monetary tightenings that were not accompanied by credit actions $(1955,1959,1981$, and 1988) all occurred during Republican administrations.

\section{CONCLUSION}

The preceding analysis suggests that to the extent that the monetary transmission mechanism has changed in recent years, it is largely because of changes in Federal Reserve policy actions, not because of changes in financial structure or regulations. The credit side of the transmission mechanism is less important today mainly because the Federal Reserve has become more willing to let high interest rates ration credit and has stopped undertaking actions aimed at reducing bank lending directly. This view of the source of changes in the transmission mechanism raises the issue of the welfare effects of the move away from credit actions.

The arguments against credit actions come naturally to economists.

26 See Shreft (1990), Economic Report of the President, 1981, and U. S. Board of Governors of the Federal Reserve System (1980b). 
Direct restrictions on bank lending make it difficult for certain borrowers to obtain loans, or force particular borrowers to pay a premium for funds that is not justified by simple differences in risk. As a result, certain borrowers are dissuaded from investment for no reason other than that they are only able to borrow from banks. Thus, Federal Reserve credit actions create an inefficiency in the provision of credit. In contrast, a reliance on interest rates assures that loans go to the borrowers who provide the highest anticipated returns.

There also does not appear to be a strong distributional argument in favor of direct credit actions. On the one hand, small firms are particularly dependent on banks for finance; thus actions that directly restrict bank lending would tend to have a disproportionate impact on small firms. On the other hand, when the Federal Reserve has taken direct credit actions, it has generally also used moral suasion to attempt to shift the composition of banks' lending toward smaller firms; these attempts may have served to reduce the impact of the credit actions on small firms. The net impact of these forces is not clear, but there is certainly no evidence that direct credit actions have insulated small firms from the impact of tight policy.

Thus, arguments in favor of continued reliance on credit actions must rely on market imperfections or political considerations. For example, if one believes that bank regulations are inadequate or that deposit insurance creates incentives for banks to make risky loans and that these problems are more serious in times of tight monetary policy, then direct restrictions on bank lending may be appropriate. Similarly, if one believes, following Wojnilower (1980), that high interest rates must ultimately lead to a credit crunch, then it may be desirable for the Federal Reserve to crunch by design, rather than to allow a crunch by accident. Finally, if one believes that high interest rates may lead to legislation that regulates interest rates 
or reduces the Federal Reserve's independence, credit actions may be the most prudent way to restrain credit flows.

The recent monetary contractions where credit actions were not used seem to contradict such arguments. In both the 1981-1982 recession and the 1988 monetary shock, high interest rates did not lead to bank insolvency, accidental credit crunches, or harmful legislation. Monetary tightening without credit actions was adequate for achieving the desired slowdowns in economic activity and inflation. Thus, credit actions are not a necessary tool of monetary control. 


\section{REFERENCES}

Bernanke, Ben S. "Credit in the Macroeconomy." Federal Reserve Bank of New York Quarterly Review 18 (Spring 1993), pp. 50-70.

Bernanke, Ben S. and Alan S. Blinder. "Credit, Money, and Aggregate Demand." American Economic Review 78 (May 1988), pp. 435-439.

Bernanke, Ben S. and Alan S. Blinder. "The Federal Funds Rate and the Channels of Monetary Transmission." American Economic Review 82 (Sept. 1992), pp. 901-921.

Bernanke, Ben S. and Cara S. Lown. "The Credit Crunch." Brookings Papers on Economic Activity (1991:2), pp. 205-239.

Bosworth, Barry. "Institutional Change and the Efficacy of Monetary Policy." Brookings Panel on Economic Activity (1989:1), pp. 77-110.

Boyd, John and Mark Gertler. "U.S. Commercial Banking: Trends, Cycles and Policy." Mimeo, University of Minnesota and New York University, February 1993. Forthcoming in NBER Macroeconomics Annual.

Burger, Albert E. "A Historical Analysis of the Credit Crunch of 1966." Federal Reserve Bank of St. Louis Review 51 (September 1969), pp. 13-30.

Cantor, Richard and John Wenninger. "Perspective on the Credit Slowdown." Federal Reserve Bank of New York Quarterly Review 18 (Spring 1993), pp. 3-36.

Friedman, Benjamin M. "Changing Effects of Monetary Policy on Real Economic Activity." In Monetary Policy Issues in the 1990s (Kansas City: Federal Reserve Bank of Kansas City, 1989), pp. 55-111.

Gertler, Mark and Simon Gilchrist. "Monetary Policy, Business Cycles and the Behavior of Small Manufacturing Firms." Mimeo, New York University and Federal Reserve Board, December 1992.

Gertler, Mark and Simon Gilchrist. "The Role of Credit Market Imperfections in the Monetary Transmission Mechanism: Arguments and Evidence." Scandinavian Journal of Economics 95 (1993), pp. 43-64. 
Kashyap, Anil K, and Jeremy C. Stein. "Monetary Policy and Bank Lending." NBER Working Paper No. 4317, April 1993. Forthcoming in N. Gregory Mankiw, ed., Monetary Policy.

Kashyap, Anil K, Jeremy C. Stein and David W. Wilcox. "Monetary Policy and Credit Conditions: Evidence from the Composition of External Finance." American Economic Review 83 (March 1993), pp. 78-98.

Kashyap, Anil K, Owen A. Lamont and Jeremy C. Stein. "Credit Conditions and the Cyclical Behavior of Inventories." Federal Reserve Bank of Chicago Working Paper No. 93-7, June 1993.

Martens, Edward J. Federal Funds: A Money Market Device. Thesis, Pacific Coast Banking School, University of Washington, Seattle, 1958.

Miron, Jeffrey A., Christina D. Romer and David N. Weil. "Historical Perspectives on the Monetary Transmission Mechanism." NBER Working Paper No. 4326, April 1993. Forthcoming in N. Gregory Mankiw, ed., Monetary Policy.

Monhollon, Jimmie R. "Regulation Q: An Instrument of Monetary Policy." Federal Reserve Bank of Richmond Monthly Review 56 (July 1970), pp. 2-8.

Morgan, Donald P. "The Lending View of Monetary Policy and Bank Loan Commitments." Mimeo, Federal Reserve Bank of Kansas City, November 1992.

Oliner, Stephen D. and Glenn D. Rudebusch. "Is There a Broad Credit Channel for Monetary Policy?" Mimeo, Federal Reserve Board, 1992.

Oliner, Stephen D. and Glenn D. Rudebusch. "Is There a Bank Credit Channel for Monetary Policy?" Federal Reserve Board, Finance and Economics Discussion Series No. 93-8, March 1993.

Owens, Raymond E. and Schreft, Stacey L. "Identifying Credit Crunches." Federal Reserve Bank of Richmond Working Paper No. 93-2, March 1993. 
Romer, Christina D. and David H. Romer. "Does Monetary Policy Matter? A New Test in the Spirit of Friedman and Schwartz." NBER Macroeconomics Annual 4 (1989), pp. 121-170.

Romer, Christina D. and David H. Romer. "New Evidence on the Monetary Transmission Mechanism." Brookings Papers on Economic Activity (1990:1), pp. 149-213.

Romer, Christina D. and David H. Romer. "Monetary Policy Matters." Manuscript, University of California, Berkeley, November 1992. Forthcoming in Journal of Monetary Economics.

Schreft, Stacey L. "Credit Controls: 1980." Federal Reserve Bank of Richmond Economic Review 76 (November/December 1990), pp. 25-55.

Wojnilower, Albert M. "The Central Role of Credit Crunches in Recent Financial History." Brookings Papers on Economic Activity (1980:2), pp. 277-326.

U.S. Board of Governors of the Federal Reserve System. Federal Reserve Bulletin. Various years.

U.S. Board of Governors of the Federal Reserve System. Introduction to Flow of Funds, 1980. (a)

U.S. Board of Governors of the Federal Reserve System. Federal Reserve Credit Restraint Program. Interim reports by the staff of the Board of Governors of the Federal Reserve System, July 21, 1980. (b)

U.S. President. Economic Report of the President. Various years. 
Table 1

Spread and Mix Regressions with Monetary Policy Dummy Variables

\author{
Cumulative Impulse Response \\ at Lag with Maximum Significance
}

Sample Monetary Policy Dummy Credit Action Dummy

(In percent, lag in brackets, t-statistics in parentheses)

Spread

1. 19641989

1.89 [7]

(4.31)

2. $1954-1992$

$1.21[7]$

(3.12)

3. $1964-1989$

1.78 [2]

(4.78)

4. $1954-1992$

$1.75[2]$

(5.09)

5: $1964-1989$

$1.41[7]$

(3.61)

1.32 [2]

6. $1954-1992$

$0.80[7]$

(2.19)

1.43 [2]

(4.07) 
Table 1 (Continued)

Cumulative Impulse Response

at Lag with Maximum Significance

Sample Monetary Policy Dummy Credit Action Dummy

(In percent, lag in brackets, t-statistics in parentheses)

$\underline{\text { Mix }}$

7. $1964-1989$

$-2.64[7]$

$(-3.29)$

8. $1954-1992$

$-2.32[7]$

$(-3.52)$

9. 19641989

$-1.92[2]$

$(-3.76)$

10. $1954-1992$

$-1.93[2]$

$(-4.33)$

11. $1964-1989$

$-1.98[7]$

$(-2.32)$

-1.51 [2]

$(-2.90)$

12. $1954-1992$

$-1.74[7]$

$-1.56[2]$

$(-2.58)$

$(-3.48)$

Note: For the regressions reported in Lines 2 and 6, the second lag is slightly more significant than the seventh lag. However, to preserve comparability with the other results, we report the cumulative impulse response and t-statistic for the seventh lag. 


\section{Table 2}

Spread and Mix Regressions with Federal Funds Rate

Cumulative Impulse Response

at Lag with Maximum Significance

Sample Change in Funds Rate Credit Action Dummy

(In percent, lag in brackets, t-statistics in parentheses)

Spread

1. $1964-1989$

$0.89[7]$

(3.91)

2. 1954-1992

$0.78[7]$

(3.84)

3. $1964-1989$

1.78 [2]

(4.78)

4. 1954-1992

$1.75[2]$

(5.09)

5. $1964-1989$

$0.69[7]$

(2.85)

1.26 [2]

(3.13)

6. 1954-1992

$0.61[7]$

1.31 [2]

(2.94) 
Table 2 (Continued)

Cumulative Impulse Response
at Lag with Maximum Significance

Sample Change in Funds Rate Credit Action Dummy

(In percent, lag in brackets, t-statistics in parentheses)

$\underline{\text { Mix }}$

7. $1964-1989$

-1.28 [3]

$(-4.53)$

8. $1954-1992$

-1.14 [3]

$(-4.71)$

9. 1964-1989

$-1.92[2]$

$(-3.76)$

10. $1954-1992$

$-1.93[2]$

$(-4.33)$

11. $1964-1989$

$-1.07[3]$

$(-3.68)$

-1.20 [2]

$(-2.26)$

12. $1954-1992$

$-0.91[3]$

$(-3.69)$

-1.29 [2]

$(-2.75)$

Note: For comparability between the two impulse response functions, the impulse to the federal funds rate is set equal to 2.84 , which is the average change in the federal funds rate from its lowest value in the two quarters before a Romer and Romer monetary policy shock and its highest value in the two quarters after. 


\title{
Table 3
}

\section{Industrial Production Regressions}

\author{
Cumulative Impulse Response \\ at Lag with Maximum Significance \\ Sample Monetary Policy Dummy Credit Action Dummy \\ (In percent, lag in brackets, t-statistics in parentheses)
}

1. $1948-1992$

$-10.82[30]$

$(-3.62)$

2. $1948-1992$

$-5.95[9]$

$(-2.38)$

3. $1948-1992$

$-10.49[30]$

$-4.15[9]$

$(-2.96)$

$(-1.60)$

Note: The data used are monthly. 


\section{Chart 1}

Treasury Bill Rate and Monetary Contractions (1947-1992)

\section{Percent}

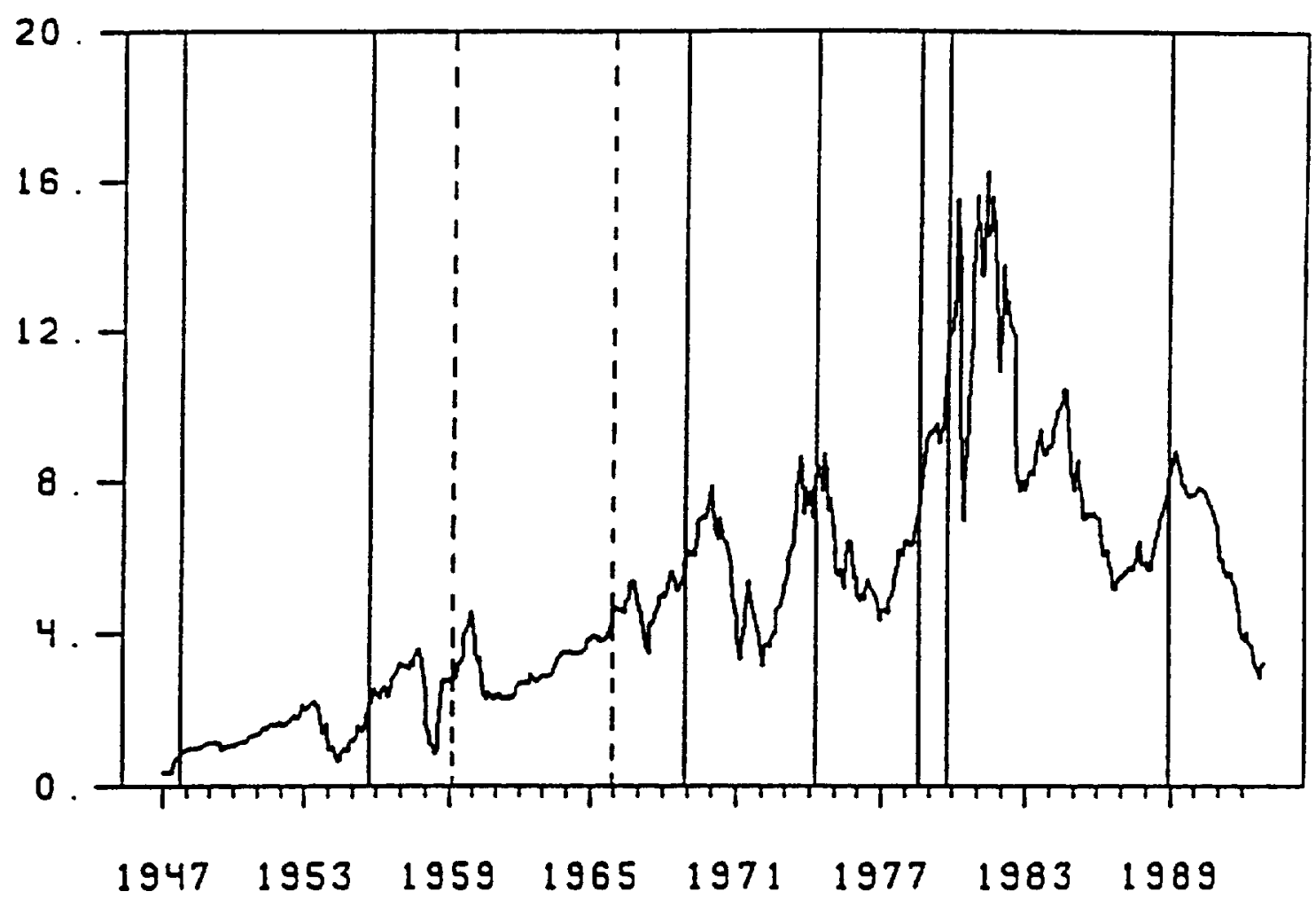




\section{Chart 2}

Federal Funds Rate and Monetary Contractions (1952-1992)

\section{Percent}

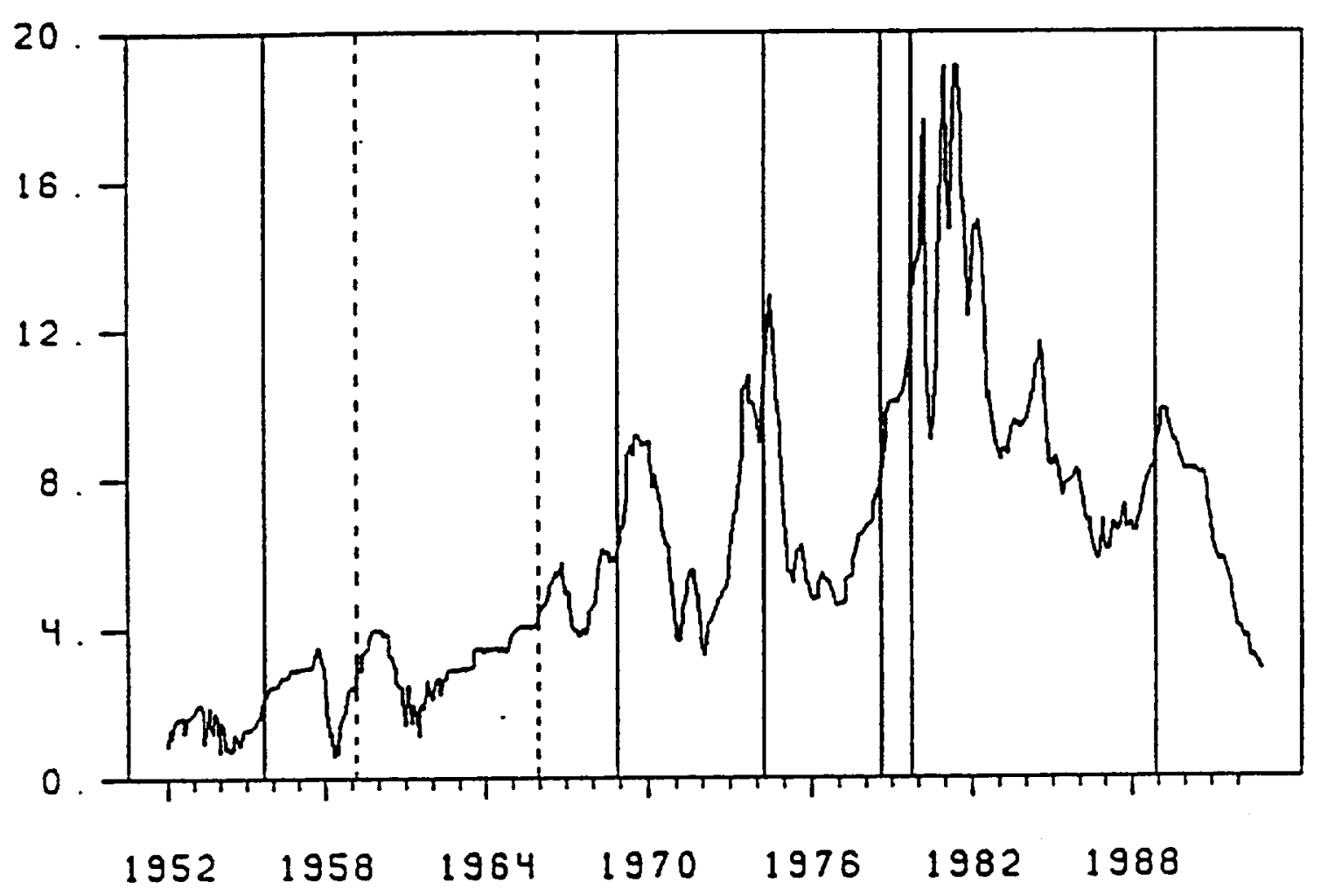




\section{Chart 3}

The Spread and Credit Actions

(1947-1992)

\section{Percent}

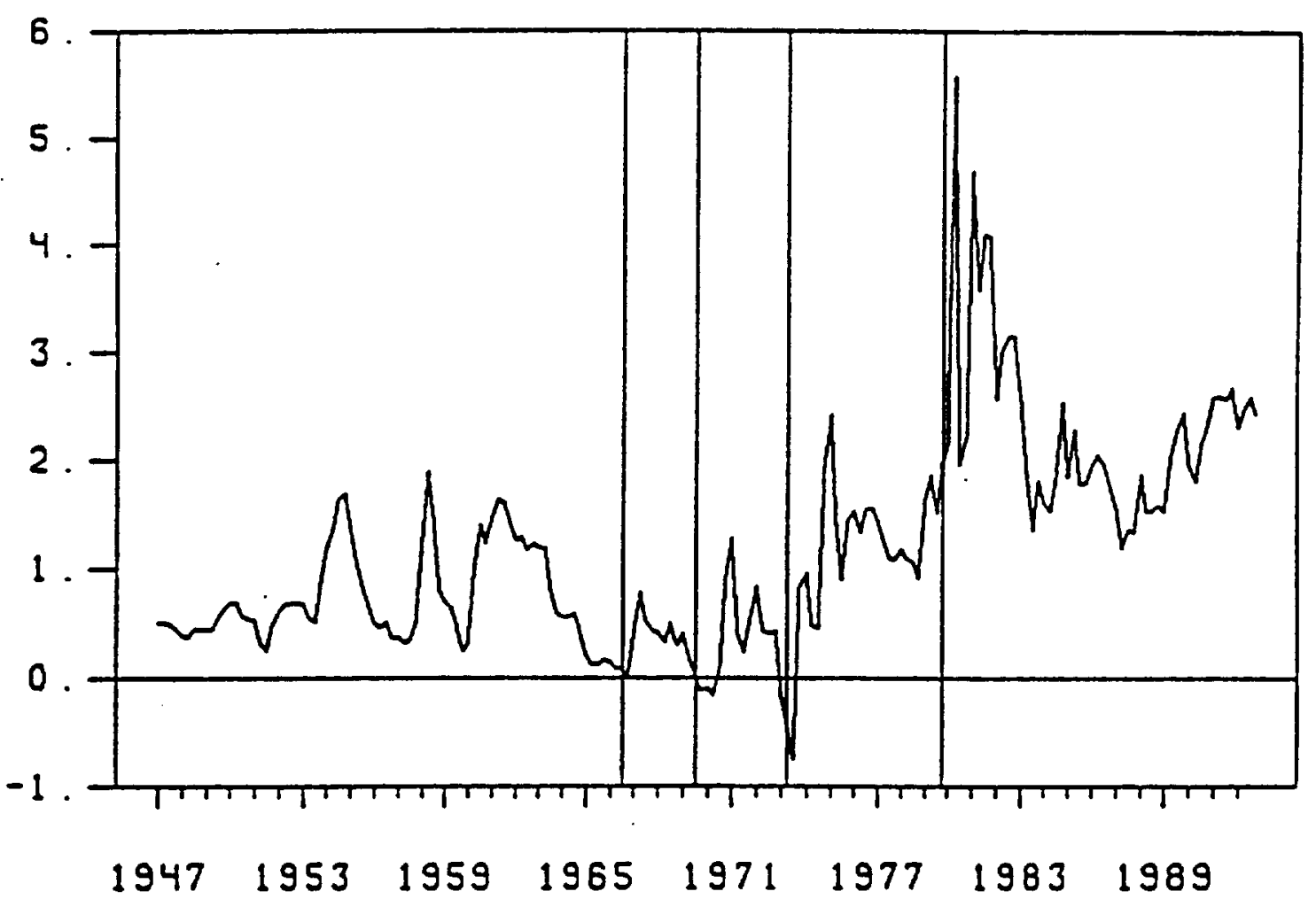


Chart 4

The Mix and Credit Actions

(1952-1992)

\section{Percent}

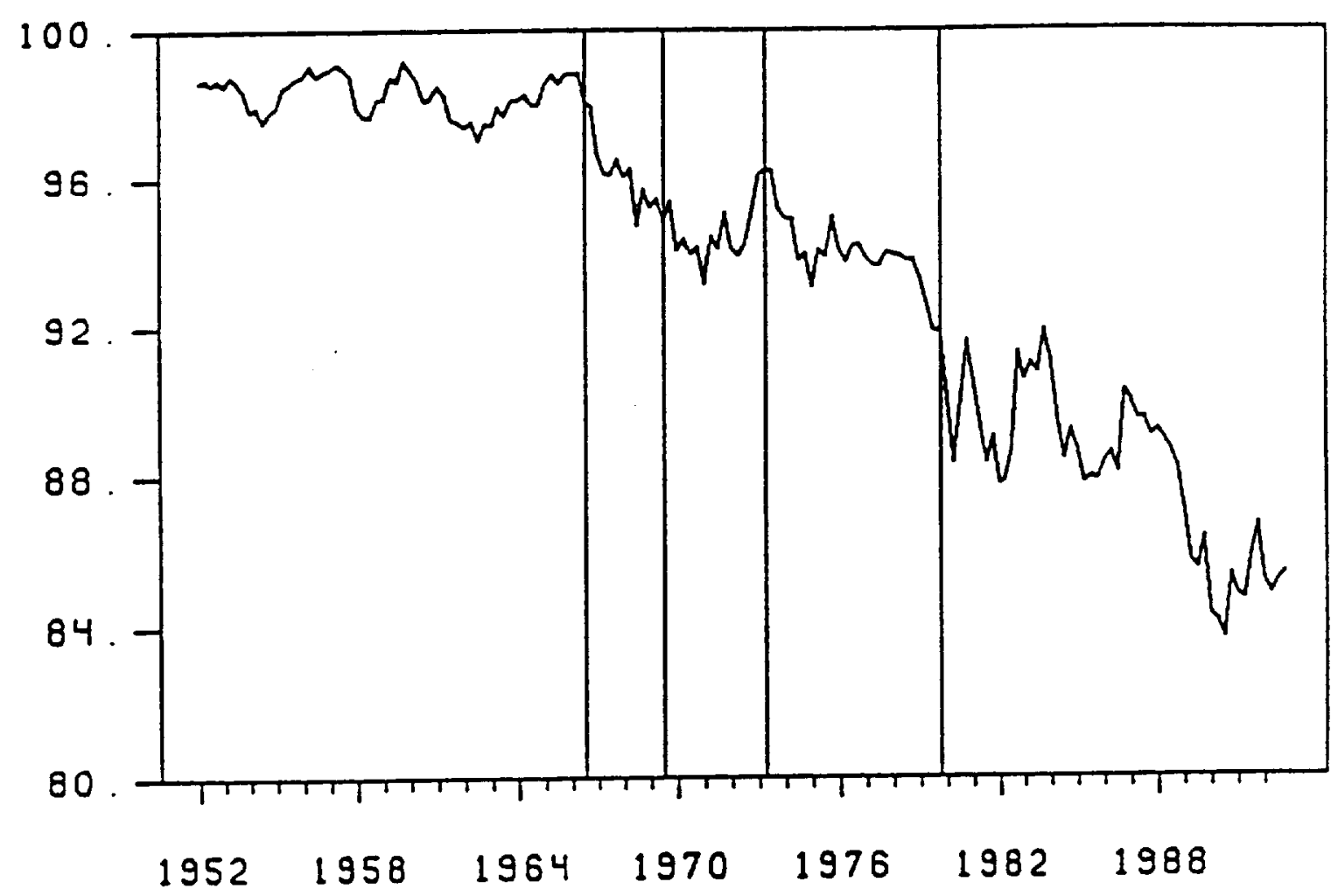




\section{Chart 5}

Impulse Response Functions for the Spread

a. Monetary Policy Dummy Variable

\section{Percent}

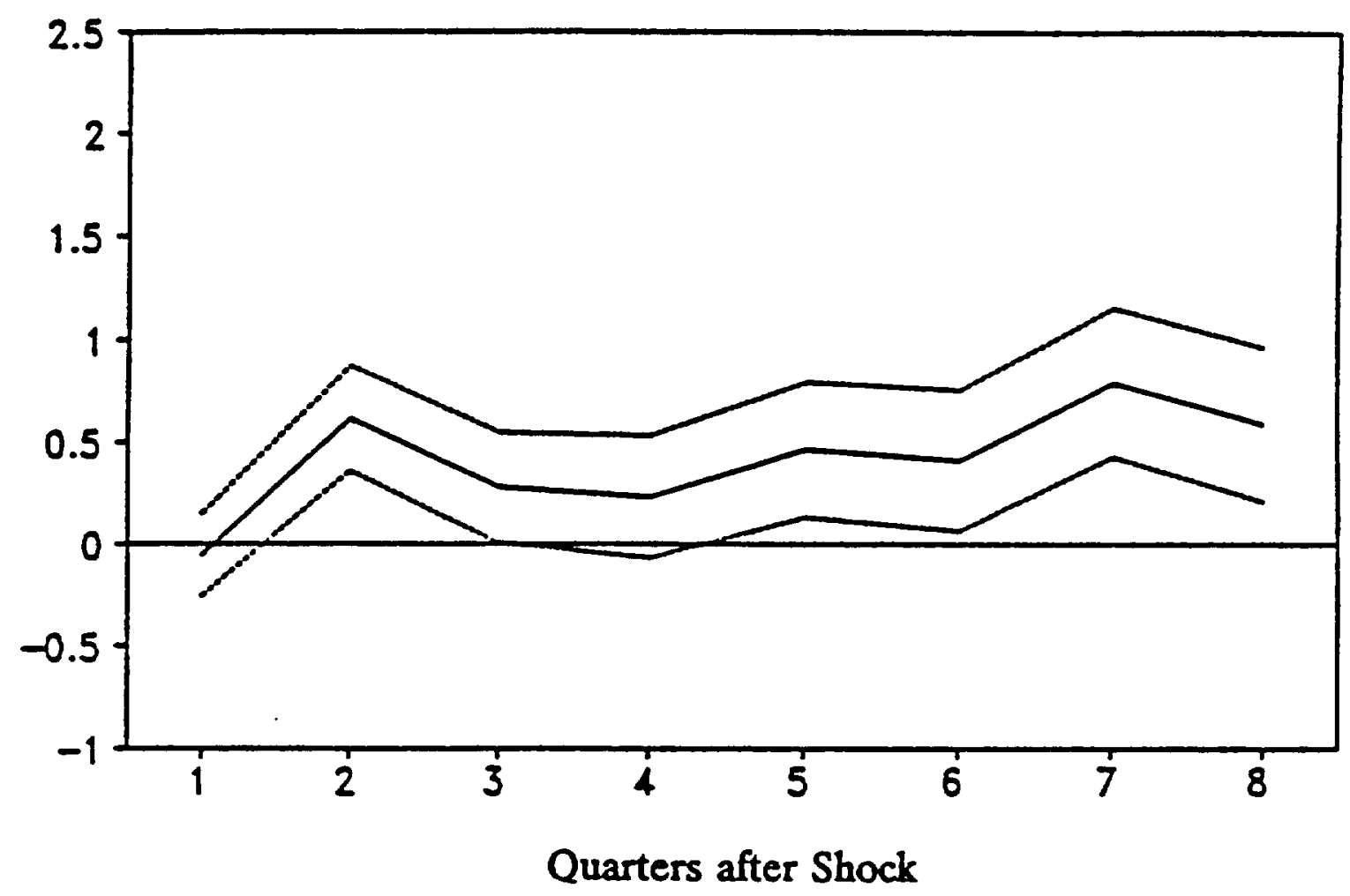




\section{Chart 5 (Continued)}

b. Credit Action Dummy Variable

\section{Percent}

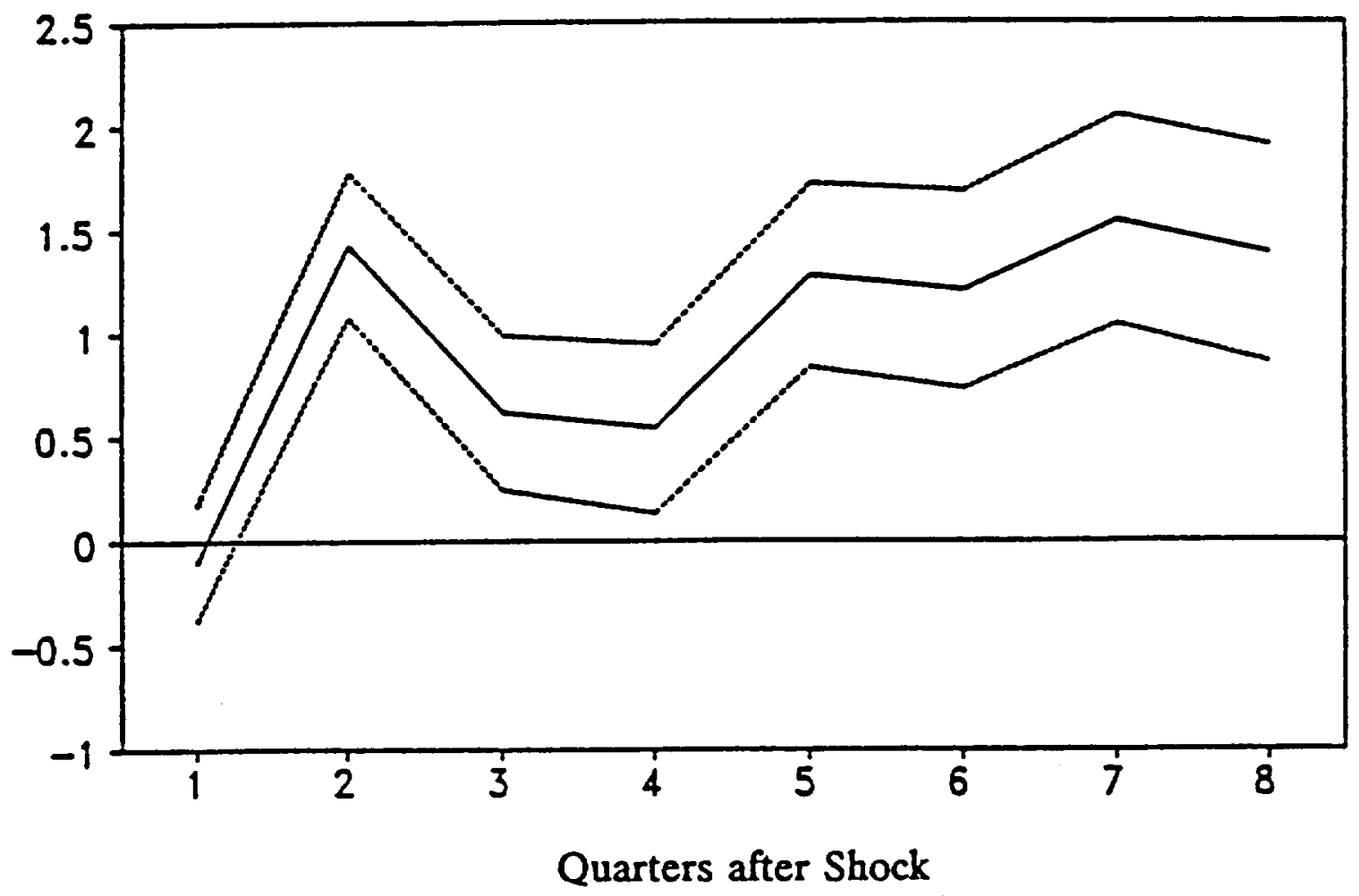

Notes: The impulse response functions are based on the regression of the change in the spread on eight own lags, eight lags of the dummy variable for monetary policy actions, and eight lags of the dummy variable for credit actions, over the sample period 1954-1992. The impulse responses have been cumulated to show the impact on the level of the spread. The dashed lines show the one standard error bands. 
Chart 6

Impulse Response Functions for the Mix

a. Monetary Policy Dummy Variable

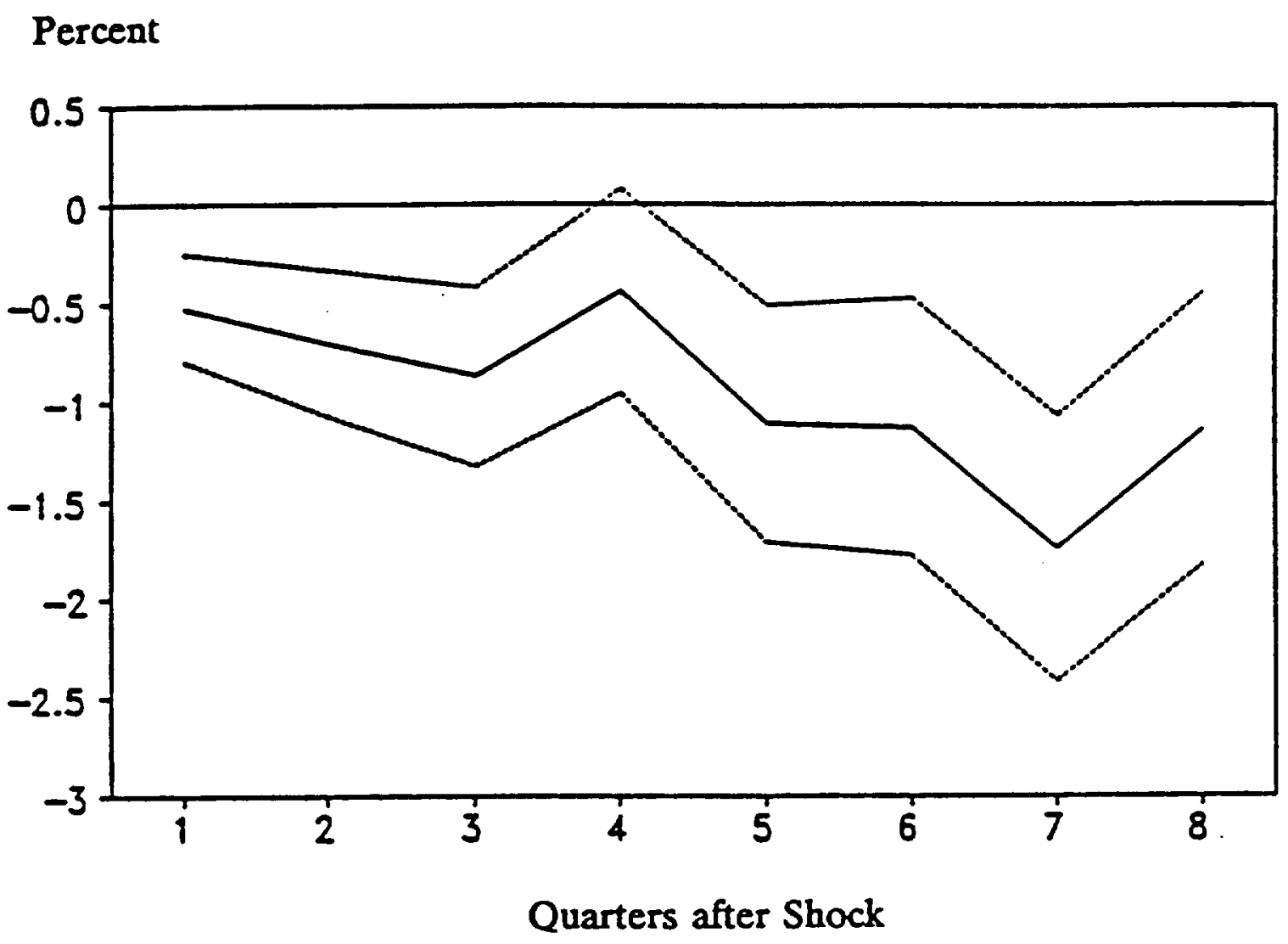




\section{b. Credit Action Dummy Variable}

\section{Percent}

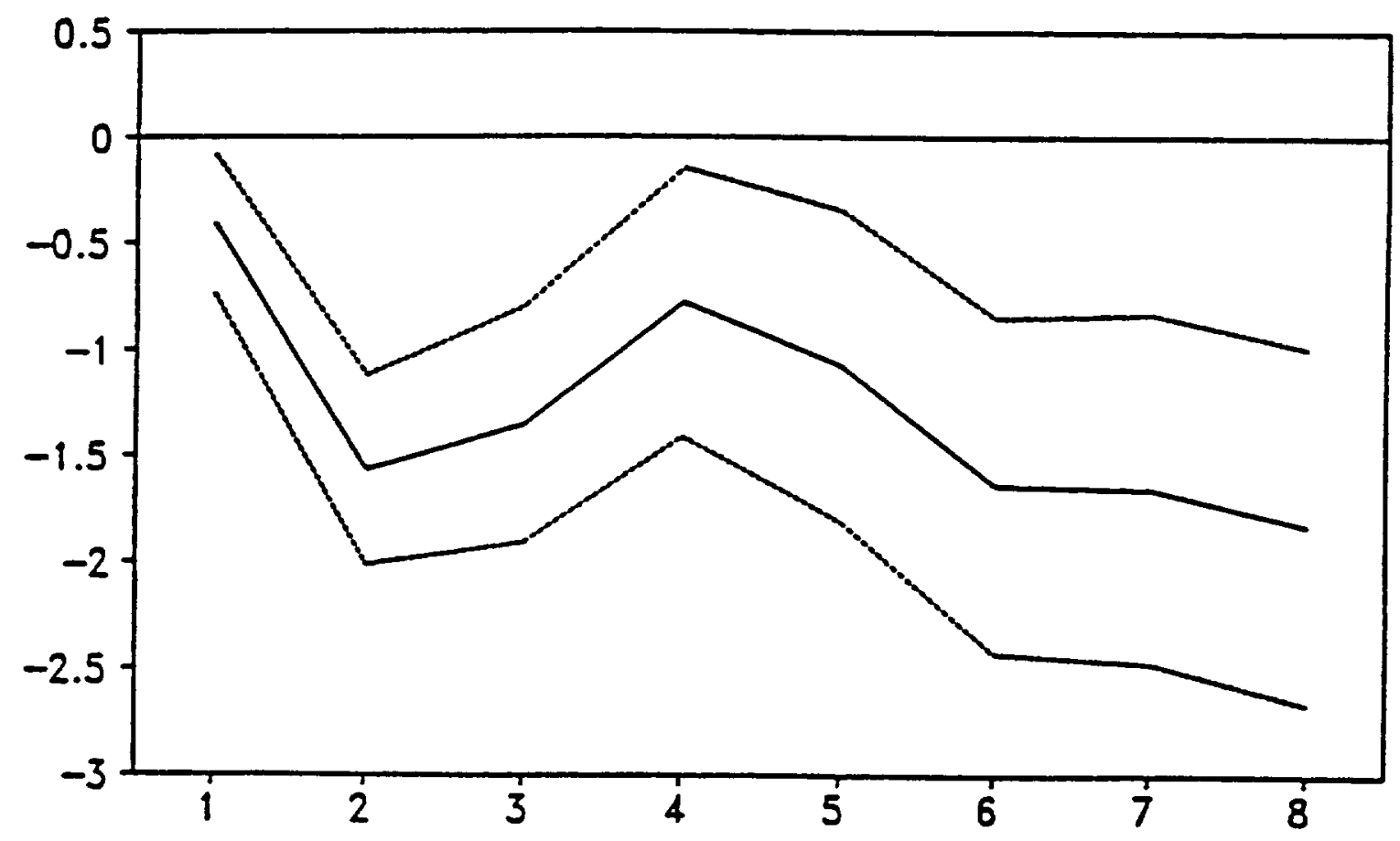

Quarters after Shock

Notes: The impulse response functions are based on the regression of the change in the mix on eight own lags, eight lags of the dummy variable for monetary policy actions, and eight lags of the dummy variable for credit actions, over the sample period 19541992. The impulse responses have been cumulated to show the impact on the level of the mix. The dashed lines show the one standard error bands. 


\title{
Chart 7
}

\section{Impulse Response Functions for the Spread}

\author{
a. Change in the Federal Funds Rate
}

\section{Percent}

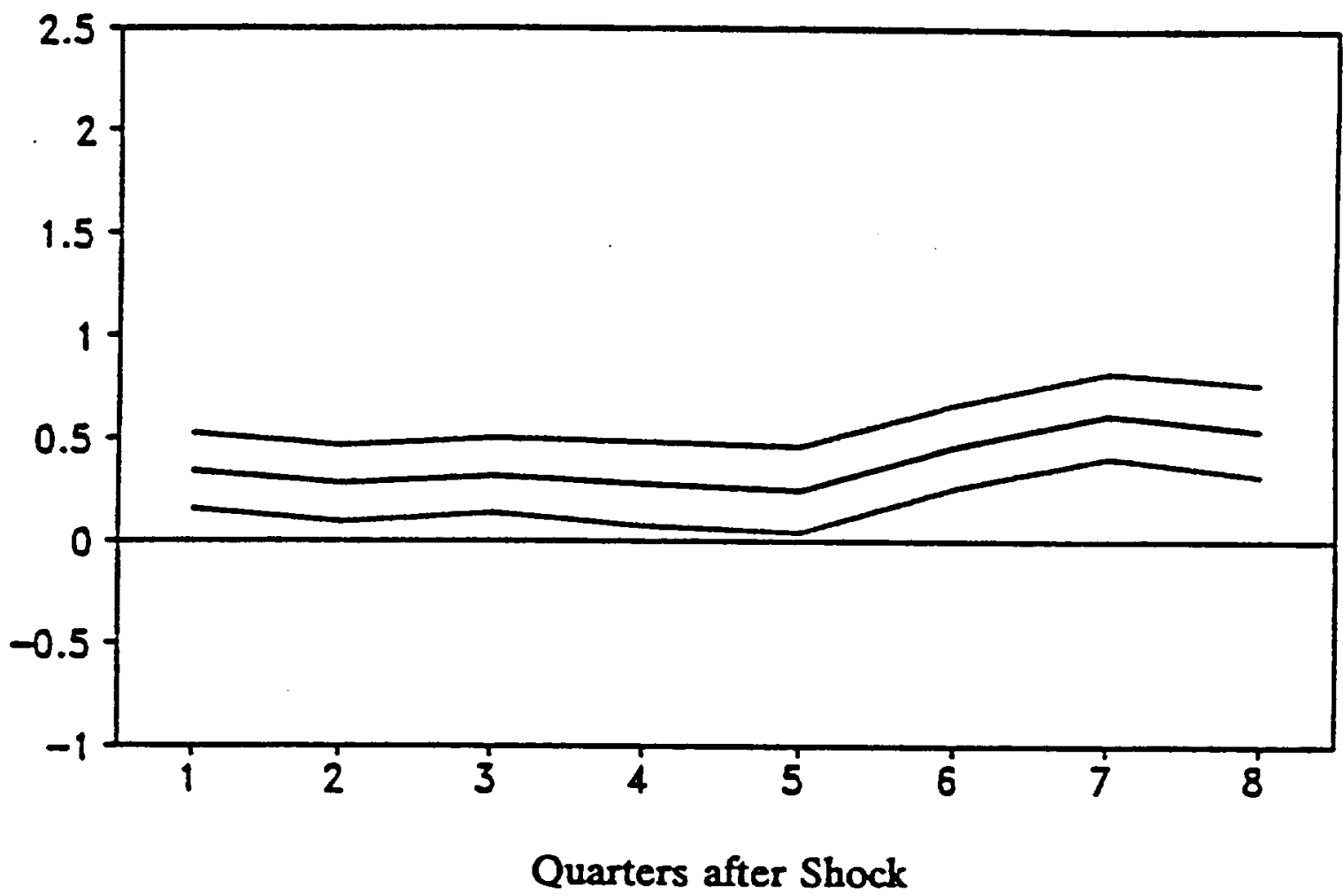




\title{
Chart 7 (Continued)
}

\author{
b. Credit Action Dummy Variable
}

\section{Percent}

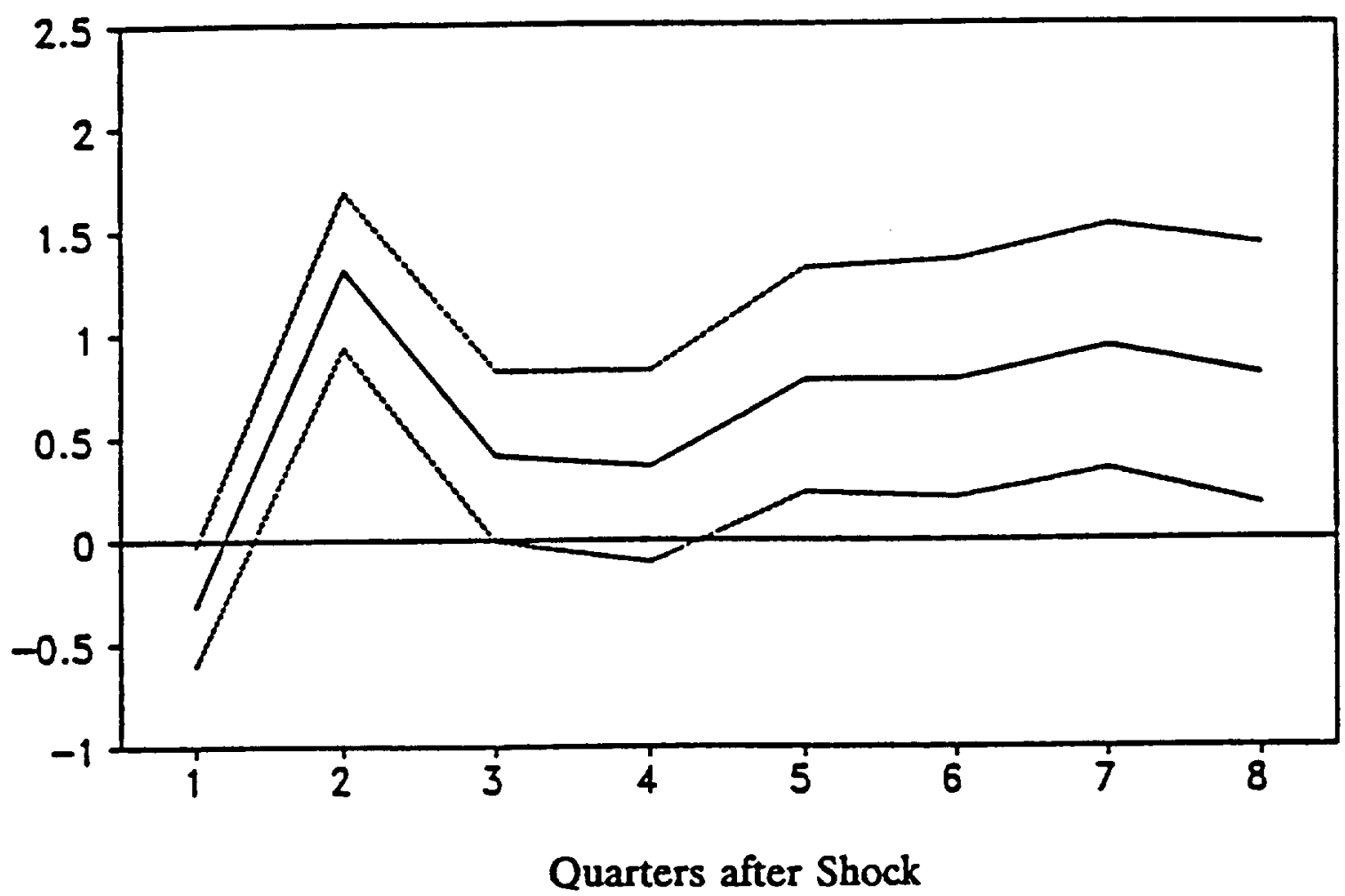

Notes: The impulse response functions are based on the regression of the change in the spread on eight own lags, eight lags of the change in the federal funds rate, and eight lags of the dummy variable for credit actions, over the sample period 1954-1992. The impulse responses have been cumulated to show the impact on the level of the spread. The dashed lines show the one standard error bands. 


\section{Chart 8}

Impulse Response Functions for the Mix

a. Change in the Federal Funds Rate

\section{Percent}

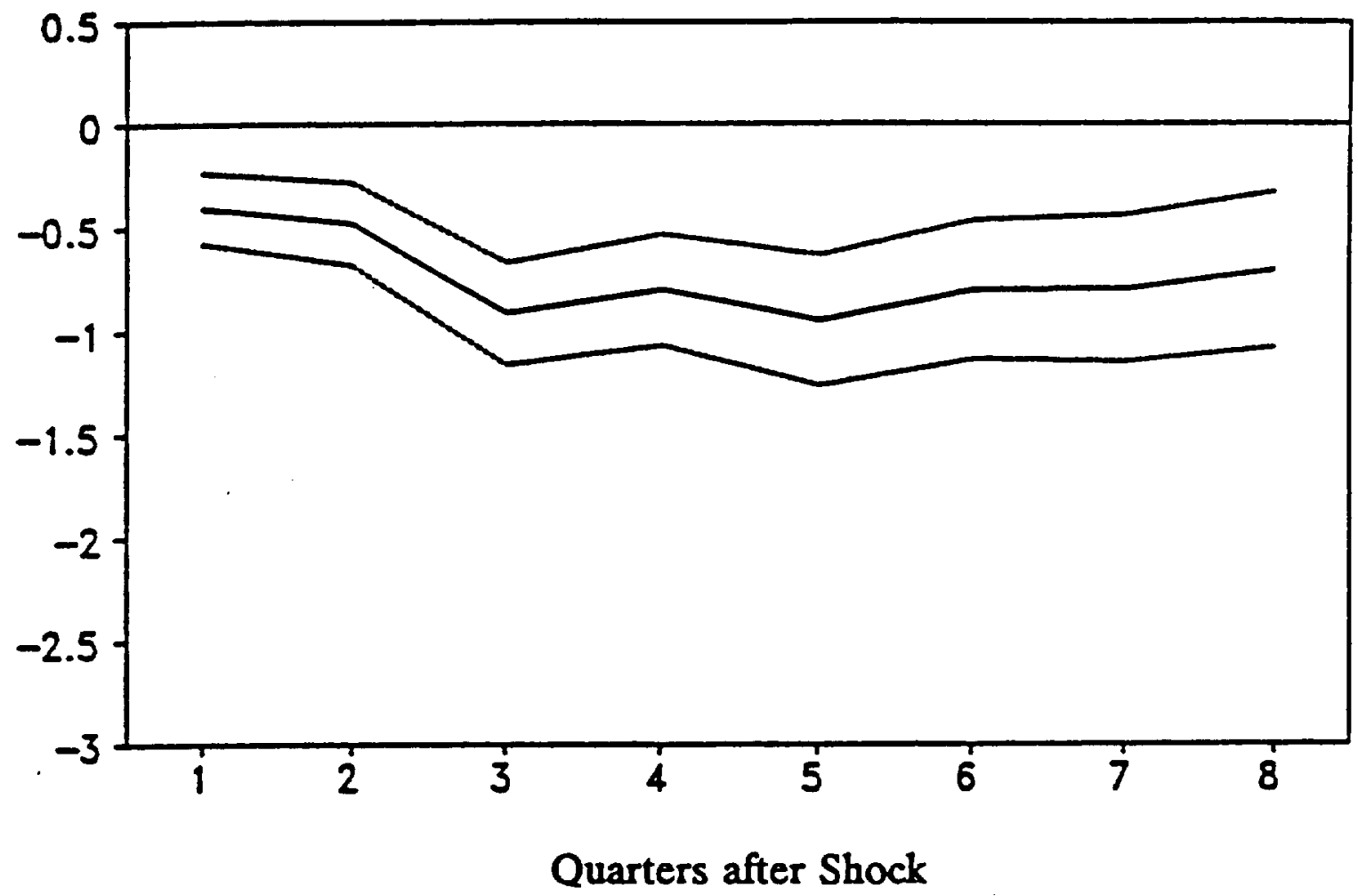


b. Credit Action Dummy Variable

Percent

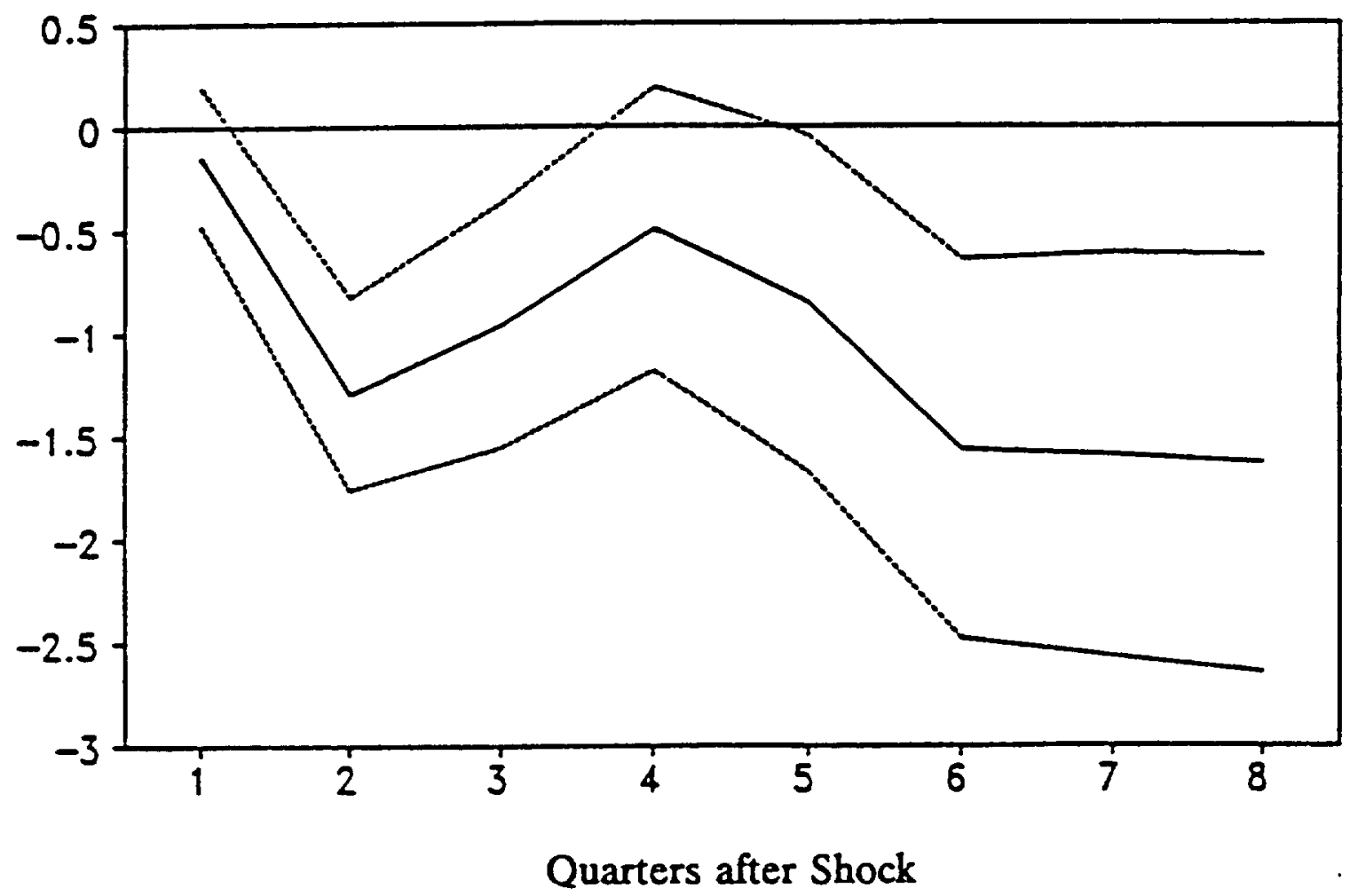

Notes: The impulse response functions are based on the regression of the change in the mix on eight own lags, eight lags of the change in the federal funds rate, and eight lags of the dummy variable for credit actions, over the sample period 1954-1992. The impulse responses have been cumulated to show the impact on the level of the mix. The dashed lines show the one standard error bands. 


\section{Chart 9}

Industrial Production and Credit Actions

(1945-1992)

\section{Percent}

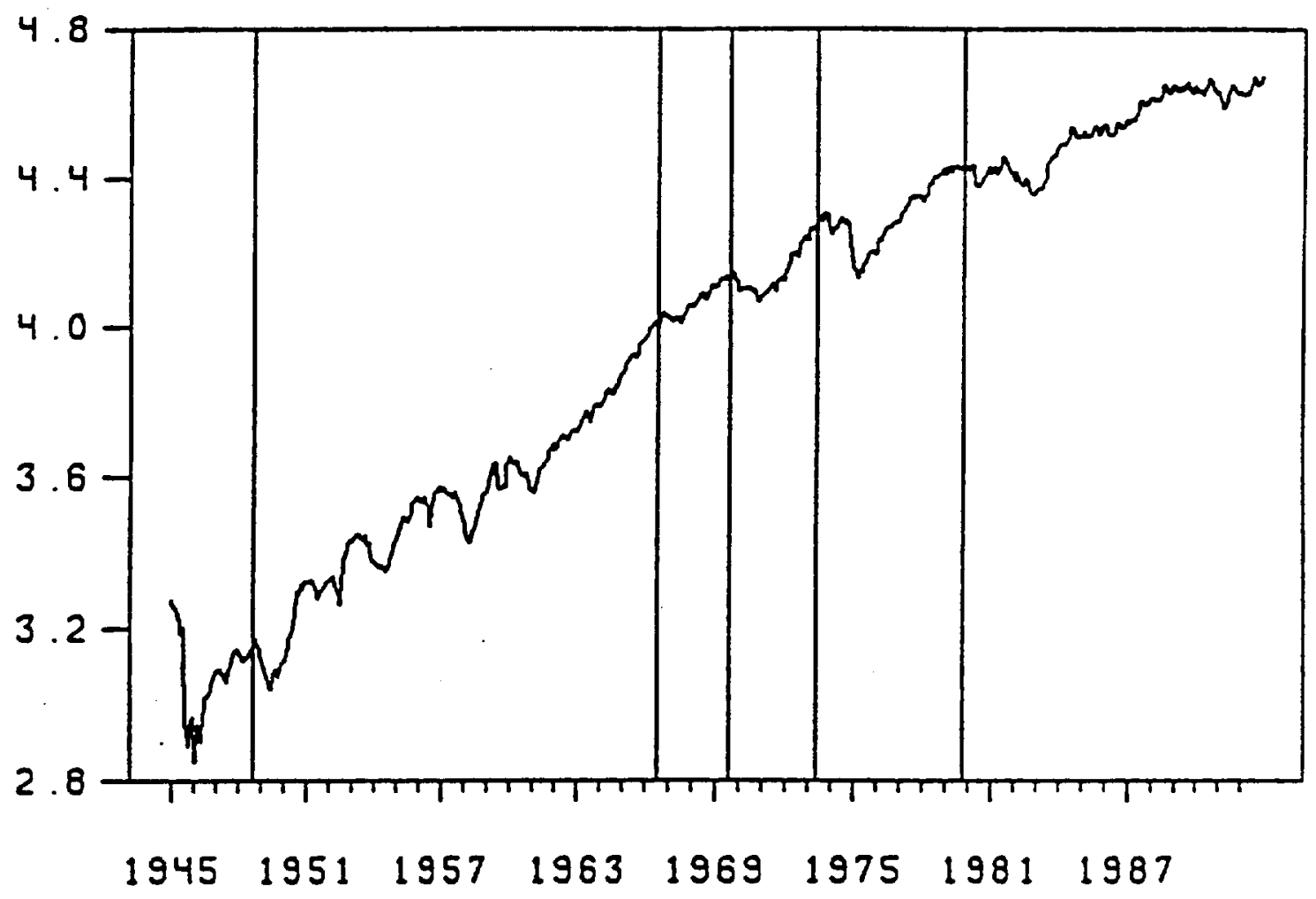




\section{Chart 10}

Impulse Response Functions for Industrial Production

a. Monetary Policy Dummy Variable

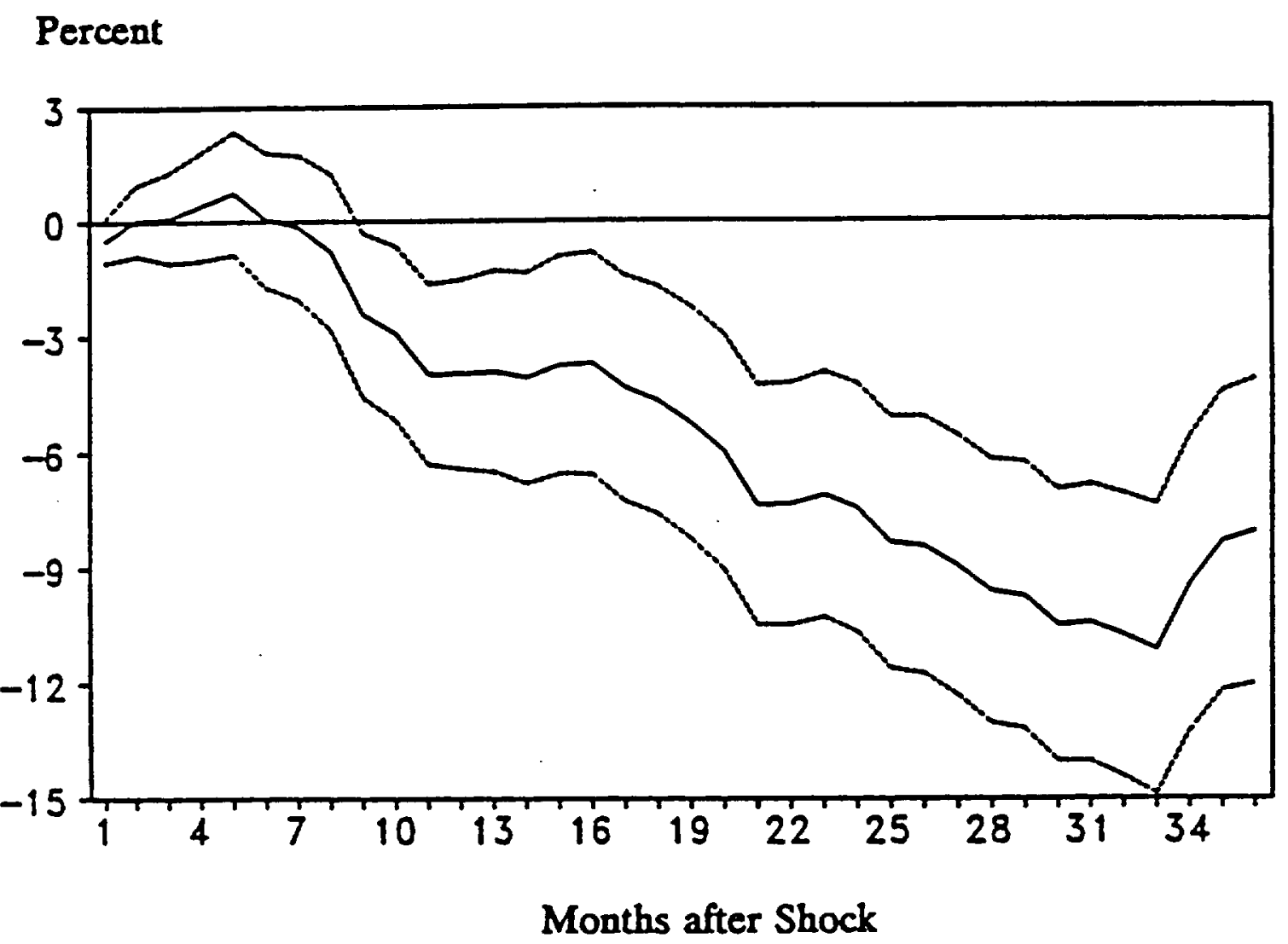


b. Credit Action Dummy Variable

\section{Percent}

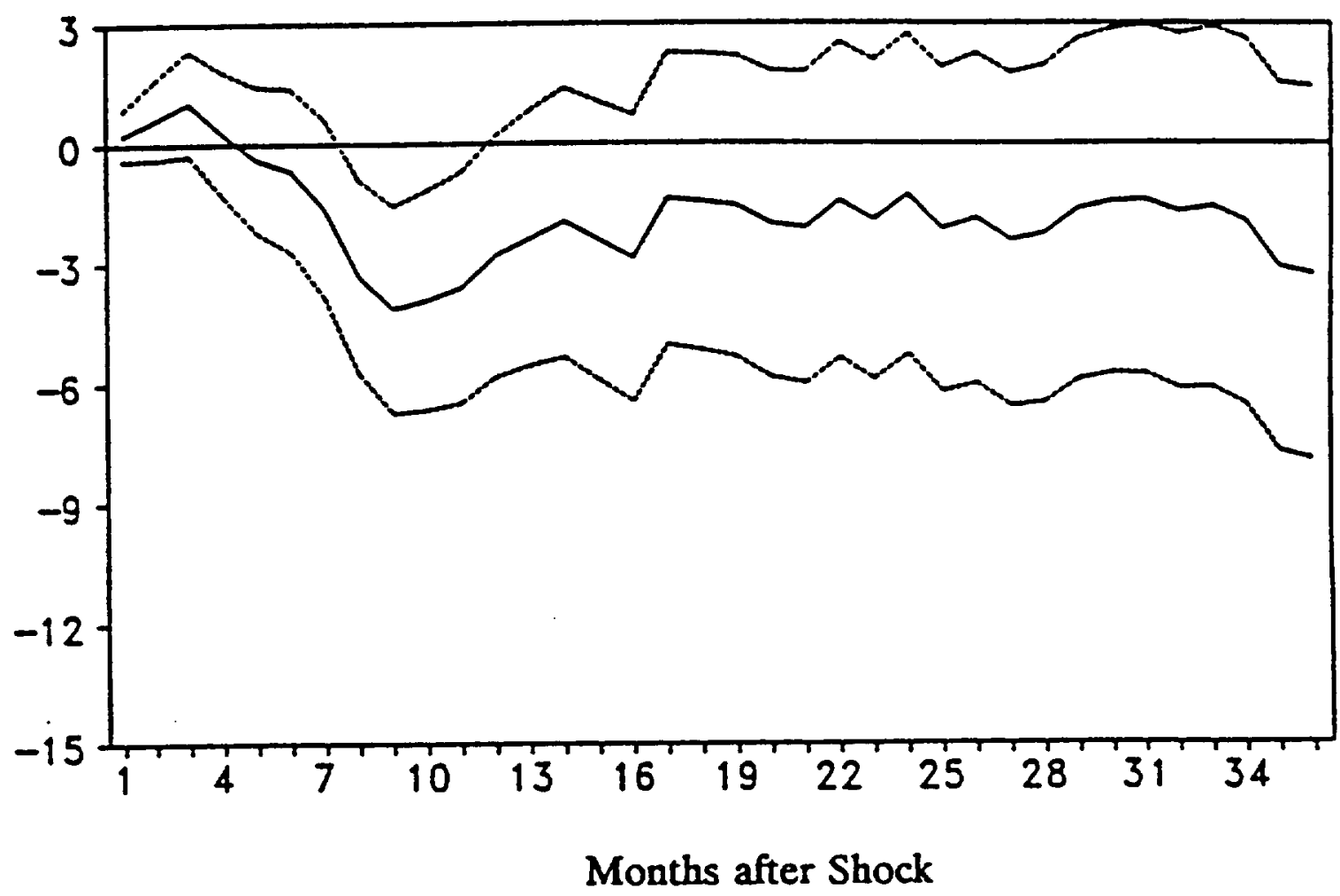

Notes: The impulse response functions are based on the regression of the change in industrial production on 24 own lags and the contemporaneous value and 36 lags of both the dummy variable for monetary contractions and the dummy variable for credit actions, over the sample period 1948-1992. The impulse responses have been cumulated to show the impact on the level of the industrial production. The dashed lines show the one standard error bands. 
Chart 11

\section{Ratio of Bank Loans to GDP \\ (1952-1992)}

\section{Percent}

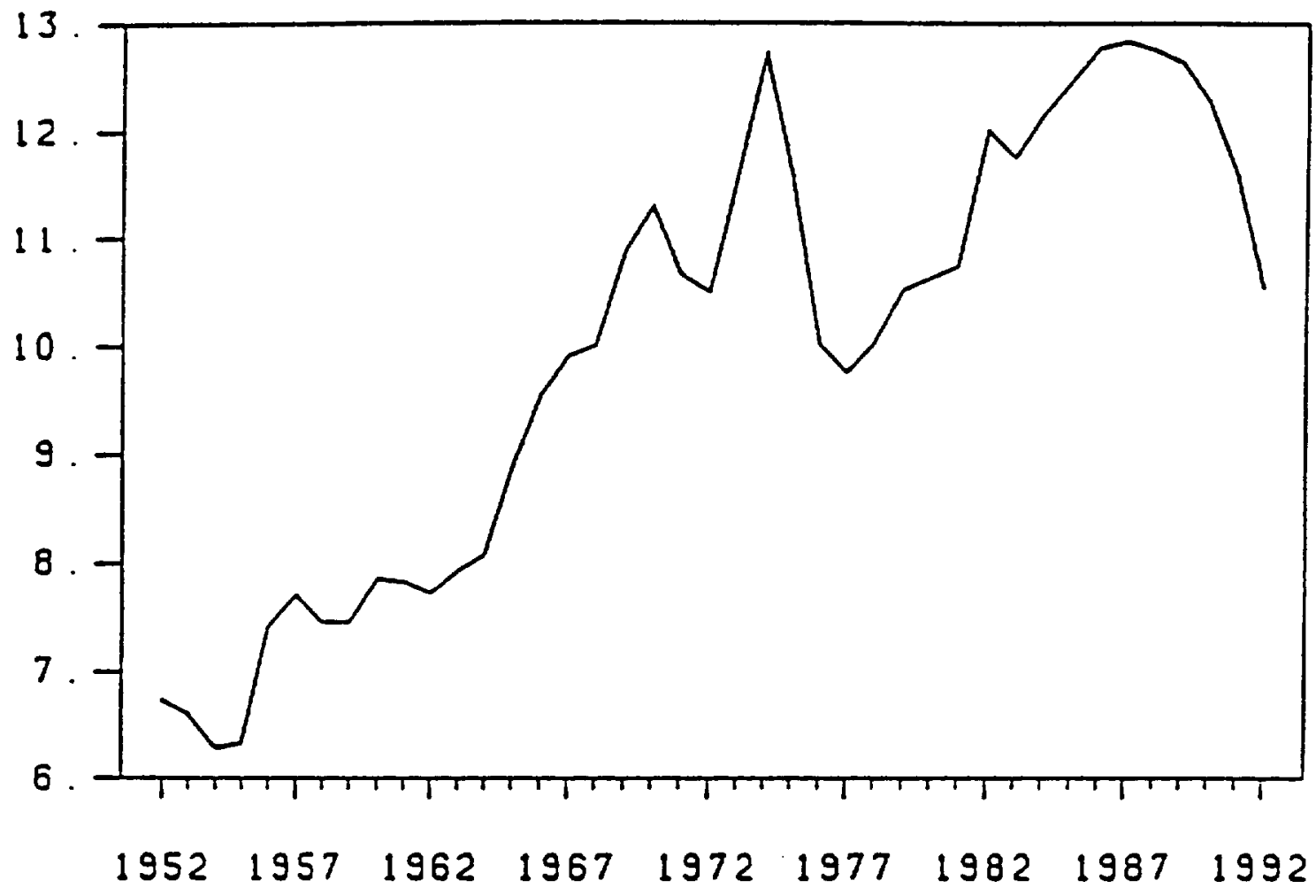

